\title{
The tumor microenvironment in hepatocellular carcinoma (Review)
}

\author{
GIULIA COSTANZA LEONARDI ${ }^{1}$, SAVERIO CANDIDO ${ }^{1}{ }^{,}$MELCHIORRE CERVELLO $^{3}$, DARIA NICOLOSI ${ }^{2}$, \\ FABIO RAITI $^{1}$, SALVATORE TRAVALI ${ }^{1}$, DEMETRIOS A. SPANDIDOS ${ }^{4}$ and MASSIMO LIBRA ${ }^{1}$ \\ ${ }^{1}$ Laboratory of Translational Oncology and Functional Genomics, Section of Pathology and Oncology, \\ ${ }^{2}$ Section of Microbiology, Department of Bio-medical Sciences, University of Catania, Catania; \\ ${ }^{3}$ Institute of Biomedicine and Molecular Immunology 'Alberto Monroy', National Research Council, Palermo, Italy; \\ ${ }^{4}$ Department of Virology, Medical School, University of Crete, Heraklion, Greece
}

Received February 21, 2012; Accepted March 19, 2012

DOI: $10.3892 /$ ijo.2012.1408

\begin{abstract}
The tumor microenvironment has been largely studied as a dynamic system orchestrated by inflammatory cells, including cancer cells, stroma as well as the extracellular matrix. It is useful to describe and predict the phenotypic characteristics of cancer. Furthermore, a better understanding of its interplay with the various aspects of the tumor cells may be utilized for the discovery of novel molecular targets. Liver cancer is considered a model of the relation occurring between the tumor microenvironment and tumor development. The chronic inflammatory status of the liver, sustained by the infection of hepatitis viruses, as well as the production of cytokines and growth factors within the parenchyma, lead to an intricate microenvironment. The identification of novel molecular therapeutic targets may improve the outcome of patients with liver cancer as it remains the third leading cause of cancer death worldwide. In the present study, the tumor microenvironment in hepatocellular carcinoma (HCC) was explored by a review of the literature. Studies on hepatitis virus infections and the consequent chronic inflammatory status were examined. In this context, immune-mediated and/or virusrelated molecular mechanisms have been hypothesized as being responsible for liver cancer development. The interlink among HCC microenvironment components, comprising cellular elements, cytokines, growth factors and several proteins is also described together with the role of matrix metalloproteinases in HCC development. Finally, the rationale for targeting tumorstromal interface is summarized in the context of new therapeutic opportunities.
\end{abstract}

Correspondence to: Dr Massimo Libra, Department of Biomedical Sciences, Pathology and Oncology Section, Laboratory of Translational Oncology and Functional Genomics, University of Catania, Via Androne 83, I-95124 Catania, Italy

E-mail: mlibra@unict.it

Key words: tumor microenvironment, hepatocellular carcinoma, liver, hepatitis, virus infections, cytokines, matrix metalloproteinases

\section{Contents}

1. Introduction

2. Viruses, inflammation and HCC

3. Components of the HCC microenvironment

4. Signaling pathways in $\mathrm{HCC}$

5. New therapeutic opportunities

6. Conclusions

\section{Introduction}

The tumor microenvironment is a changing concept that defines the behaviour of cancer not by the genetics of the tumor cells alone, but by the surrounding milieu that the tumor cells need for survival, growth, proliferation, and metastasis (1). It is a dynamic system, largely orchestrated by inflammatory cells, that includes cancer cells, stromal tissue (immune cells, fibroblasts, myofibroblasts, cytokines, and vascular tissue), as well as the surrounding extracellular matrix (2).

Although signs of 'smouldering' inflammation are present in tumors for which a firm causal relationship to inflammation has not been established (breast tumors for example), it is estimated that underlying infections (sustained by Helicobacter pylori and hepatitis viruses) and the resulting chronic inflammatory state, which can promote carcinogenesis, are linked to $15-20 \%$ of all deaths from cancer worldwide $(3,4)$. Indeed, inflammatory cells and mediators are present in the microenvironment of most, if not all, tumors, irrespective of the trigger for development (5). In addition population-based studies have shown that individuals who are prone to chronic inflammatory disorders have an increased risk of cancer development (6) and, accordingly, treatment with non-steroidal anti-inflammatory agents decreases the incidence and the mortality of several tumor types $(7,8)$.

Liver cancer is a paradigm of the relation occurring between tumor microenvironment and tumor development. The chronic inflammatory status of the liver, sustained by the infection of hepatitis viruses, as well as the production of cytokines and growth factors within the parenchyma, lead to an intricate microenvironment. 
Liver cancer is the fifth most prevalent form of cancer and the third leading cause of cancer-related deaths, immediately following lung and colon cancer throughout the world. Hepatocellular carcinoma (HCC) is the most common form of adult liver cancer, representing over $90 \%$ of all cases of primary liver cancer (9).

The majority of HCC patients have an underlying chronic inflammatory liver disease and liver cirrhosis is the main risk factor for the development of HCC $(10,11)$. Chronic liver injury is associated with dysregulated growth of hepatocytes and results in the formation of regenerative nodules, dysplastic nodules, and HCC.

In recent years, a significant amount of attention has been drawn to the concept of the tumor microenvironment in an effort to better describe and predict the phenotypic characteristics of cancer $(1,2,12)$. Moreover, a better understanding of the unique interplay between the various aspects of the tumor cells and the microenvironment may be useful for the discovery of novel molecular therapeutic targets $(13,14)$.

\section{Viruses, inflammation and $\mathrm{HCC}$}

The chronic infection sustained by hepatitis viruses (hepatitis $B$ virus, $\mathrm{HBV}$, and hepatitis $\mathrm{C}$ virus, $\mathrm{HCV}$ ) is a major risk factor for HCC development (15) and several clinical studies observed that more than $85 \%$ of HCCs worldwide retain markers for HBV and/or HCV (16-21). This causal association between viral infection and tumor development has been well established and supported in animal and epidemiological studies (22).

Much of the liver injury, characteristic of acute HBV, is caused by recruitment of inflammatory cells, consequent secretion of cytokines and the ultimate lysis of infected cells $(23,24)$. The HBV infection spread is controlled by NK cells that can directly lyse infected cells and can also down-regulate HBV replication by producing IFN- $\gamma$ and TNF- $\alpha$ (25). Moreover, IFN- $\gamma$ activates macrophages and increases TNF- $\alpha$-mediated liver damage (26). The cytotoxic T cells $\left(\mathrm{CD}^{+}\right)$are involved in the recognition of viral peptides derived from phagocytized and proteolytically cleaved HBV proteins, in the activation and differentiation of B cells, and secrete IFN- $\gamma$ and TNF- $\alpha$, which inhibit the replication and gene expression of HBV. Results from transgenic mouse studies showed that chronic HBV-specific $\mathrm{T}$ cell-mediated liver disease was sufficient to induce HCC in HBV in vivo models (27).

The immunopathology of HCV infection is largely represented by an unspecific immune response against the virus sustained by a cytokine context that recruits non-specific lymphocytes $(28,29)$, furthermore no HCV-neutralizing antibody has been detected (30). In the absence of viral clearance, this pathway boosts itself, leading to necro-inflammatory and fibrotic liver disease.

Furthermore, hepatic viruses are able to systematically evade the immune system and persist in the host through their ability to mutate under immune pressure $(31,32)$ and therefore produce variation within $\mathrm{T}$ cell epitopes that may down-regulate T cell functions leading to an inhibition of the immune response against the original epitope (33-35).

Overall, in this context an immune-mediate mechanism may be responsible of liver cancer development (Fig. 1). The chronic cell damage and regeneration processes, mediated by viral hepatitis-induced immune responses, may lead to liver cancer by promoting cell proliferation and death $(24,29,36)$. The necrosis of hepatocytes, as a result of chronic inflammation and consequent regeneration, enhances mutagenesis in host cells, which can accumulate and culminate in HCC $(23,24,28)$. The risk of developing HCC increases the longer the viral infection-induced inflammatory process lasts $(22,37)$. A general well-defined consequence of chronic inflammation is the release of free radicals, such as reactive oxygen species and NO reactive species (38). The exposure of liver tissue to oxyradical injury may lead to post-translational modification at critical residues of p53 protein (39) and accumulation of DNA adducts in HBV-transgenic mouse have been associated with HCC progression (40).

Virus-related molecular mechanisms can also be identified in liver cancer development (Fig. 1). HBV and HCV are involved in the genesis of HCC through the alterations of DNA repair system and centrosome duplication mechanisms, and through the viral-encoded oncoproteins that have transforming capability by disruption of gene expression and signaling pathways (41-44). In addition, several proteins encoded by HCV and HBV are able to directly alter cytokine expression and finally directly modulate the tumor microenvironment and the immune response in the liver, contributing to $\mathrm{HCC}$ development. A meaningful example is $\mathrm{HCV}$ p2 $1^{\text {core }}$, a viral structural protein that has been shown to play several roles: a) to decrease the production of IFN- $\gamma$ and IL-2; b) to suppress HCV-specific CTL responses (45); c) to bind the TNF receptor I (TNFRI) and the TNF-related lymphotoxin receptor modulating the signal of these cytokines (46); d) to activate the IL-2 promoter through the NFAT pathway and suppress the immunity by inhibiting IL-12 and NO production from macrophages (47); e) to down-regulate MHC class II genes in B cells and prevent B cell apoptosis (48). The HCV envelope protein, E2, inhibits NK cell function by binding CD81 on NK cells (49). In addition, the non-structural HCV phosphoprotein, NS5A, through its ability to inhibit IFN- $\alpha$ induced protein kinase, is implicated in mediating HCV resistance to IFN- $\alpha$ (50). Among $\mathrm{HBV}$ encoded protein, $\mathrm{HBx}$ can activate two transcription factors, NF- $\kappa$ B and NFAT, implicated in the expression of important cytokines, such as IL-6, IL-8, TNF- $\alpha$, and modulates the function of the inflammatory mediators including IL-8, ICAM-1 and MHC factor (51).

In the context of hepatitis virus infections, both immunemediate and molecular mechanisms of HCC development may also be associated with the development of extrahepatic lymphoproliferative disorders such as type II mixed cryoglobulinemia syndrome and B cell non-Hodgkin's lymphoma (52-62).

\section{Components of the HCC microenvironment}

Components of the HCC microenvironment comprises cellular elements, cytokines, growth factors and several proteins. Their linkage is described in Fig. 2.

Cancer-associated fibroblasts $(C A F s)$. CAFs are a central elements of tumor microenvironment. They are the most prominent cell type within the tumor stroma of many cancers and play a critical role in tumor-stromal interactions (63-65). CAFs are involved in HCC growth and invasion, as they are able to produce epidermal growth factor (EGF), fibroblast growth factor (FGF), 


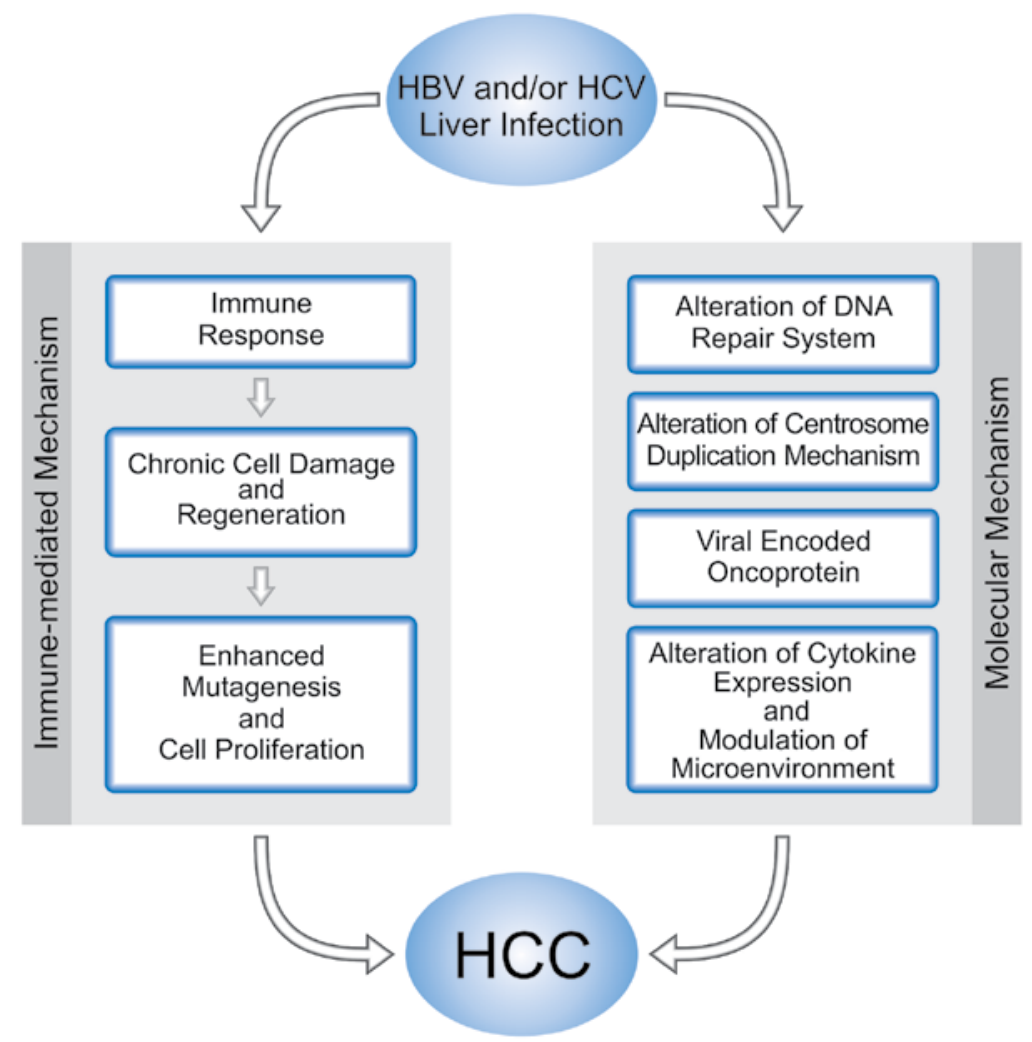

Figure 1. Representative scheme of the immune-mediate and viruses-related molecular mechanisms responsible of liver cancer development. HBV, hepatitis B virus; $\mathrm{HCV}$, hepatitis $\mathrm{C}$ virus; $\mathrm{HCC}$, hepatocellular carcinoma.

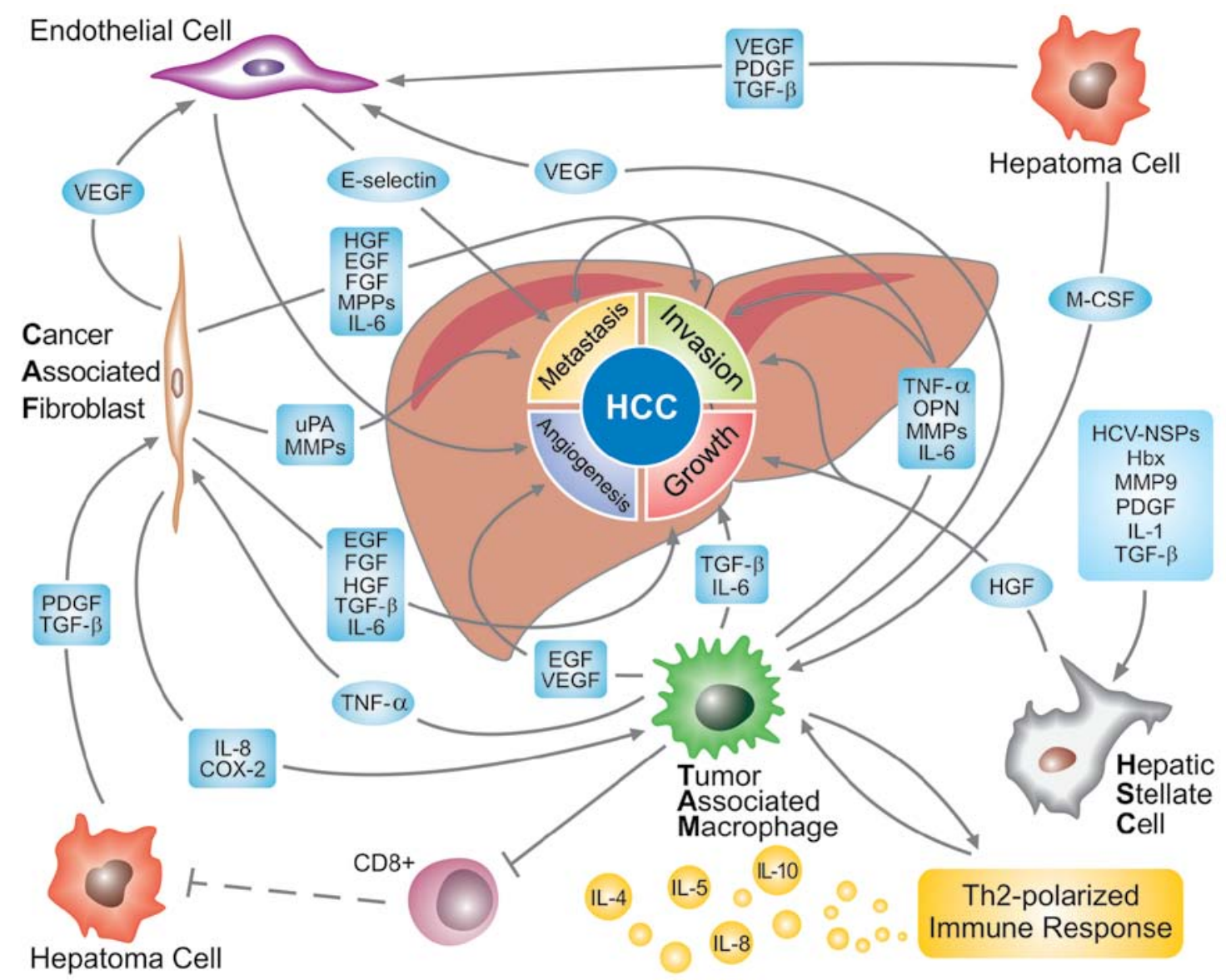

Figure 2. Hepatocellular carcinoma (HCC) microenvironment components and their linkage. Refer to the text for abbreviations. 
hepatocyte growth factor (HGF), cytokines (IL-6), chemokines (stroma-derived SDF-1/CXCL12) and metalloproteases (MMP-3 and MMP-9) (65-67). CAFs secrete also interleukin-8, COX-2 and secreted protein acidic rich in cysteine (SPARC) to recruit and stimulate macrophage production, which can increase the activation of CAFs through secretion of TNF- $\alpha$ and PDGF $(68,69)$. Experiments on invading co-cultures of cancer cells and CAFs revealed that the leading cells to tumor progression are always CAFs and that cancer cells would move into the ECM behind the CAF (70). Thus, HCC cell growth and metastatic spread are dependent upon the presence of CAFs and HCC cells reciprocally stimulate their proliferation (71).

Hepatic stellate cells (HSCs). HSCs, or Ito cells, are perisinusoidal cells whose activation is responsible for collagen synthesis in the liver (72). In response to a repeated liver injury, HSCs are activated and thus they trans-differentiate into myofibroblastlike cells. This phenotypical transformation is recognized as a central event in the development of hepatic fibrosis (73) in which activated HSCs are responsible for the production of cytokines, chemokines, growth factors and an extensive ECM $(74,75)$. HSC/myofibroblasts also infiltrate the stroma of liver tumors and localize around tumor sinusoids, fibrous septa and capsules $(11,76)$. Specifically, the conditioned media collected from HSCs induces proliferation and migration of $\mathrm{HCC}$ cells in culture, moreover through the activation of NF- $\mathrm{KB}$ and extracellular-regulated kinase (ERK) pathways, HCSs promote HCC growth and reduce the extent of central necrosis (11). Xia et al showed how HCC cells are able to promote HSC activation in rat cell culture (77). Accordingly, co-culture of HSCs with HCC cells stimulated HSC proliferation, migration and expression of proangiogenic genes such as VEGF-A and MMP-2 (78). Hepatitis B virus $\mathrm{X}$ protein, and $\mathrm{HCV}$ non-structural proteins, MMP-9, PDGF, TGF- $\beta 1$, JNK, insulin-like growth factor binding protein 5 , cathepsins $\mathrm{B}$ and $\mathrm{D}$, are potent inducers of Ito cell activation, proliferation and therefore enhance liver fibrosis and carcinogenesis (79-87).

Tumor-infiltrating leukocytes. A leukocyte infiltrate, varying in size, composition and distribution, is present in most tumors. Its components include TAMs and related cell types, mast cells and $\mathrm{T}$ cells. Evidence, based on adoptive-transfer studies, celldepletion studies, clinical correlations and gene-manipulation studies, showed that each of these bone-marrow derived components can be involved in carcinogenesis and/or tumor invasion and metastasis (88-90).

Tumor-associated macrophages (TAMs) form the basis for the model that leukocyte infiltrates are involved in tumor progression. They are located in tumor stroma and can undertake a wide spectrum of polarized activation states. Interleukin- 4 , interleukin-10, transforming growth factor- $\beta$ (TGF- $\beta$ ) found within the tumor microenvironment promotes TAM polarization towards M2 activated cells $(91,92)$. M2-like TAM expresses a distinctive set of cytokines, such as IL-10 and TGF- $\beta(93,94)$ and chemokines including CCL17, CCL22 and CCL24 favouring regulatory $\mathrm{T}$ cell (Treg) recruitment and development of an ineffective Th2 polarized immune response $(93,95)$. Moreover, M2 macrophages support tissue repair and remodelling, as well as angiogenesis through the production of VEGF or EGF (93). It has also been found that, Kupffer cells, that are liver-specific TAMs, are able to impair T cell CD8 ${ }^{+}$ dependent immune response through the interaction between programmed death 1 (PD1) on $\mathrm{T}$ cell $\mathrm{CD}^{+}$and programmed death ligand-1 (PD-L1) produced by Kupffer-TAMs causing the deficiency of $\mathrm{TCD}^{+}$cytotoxic function in HCC (96). Accordingly blocking the interaction between PD-L1 and PD1 restores $\mathrm{CD} 8^{+}$activity (97). Moreover, Kupffer cells, as well as stellate cells, when stimulated by inflammatory cytokines (IL-1, TNF- $\alpha$, PDGF), produce excessive osteopontin that plays a pivotal role in various cell signaling pathways that promote inflammation, tumor progression and metastasis $(98,99)$.

Lymphocytes can be consistently observed in a variety of human cancers, and in some cases these infiltrating lymphocytes correlate with a favourable prognosis (100). However, not all $\mathrm{T}$ cells are anti-tumor effector immune cells. A subpopulation of $\mathrm{T}$ cells $\mathrm{CD} 4^{+} \mathrm{CD} 25^{+} \mathrm{Foxp}^{+}$, called Tregs (regulatory $\mathrm{T}$ cell), plays a pivotal role in promoting tumor growth and progress by inhibiting the immune response against cancer (101). Regarding HCC, it has been demonstrated that Tregs were more predominant than $\mathrm{T} \mathrm{CD}^{+}$in $\mathrm{HCC}$ tissues in comparison with nearby benign tissues and that Tregs prejudice $\mathrm{T} \mathrm{CD} 8^{+}$proliferation, activation, degranulation and production of granzymes and perforin (102). Moreover, low intratumoral $\mathrm{T} \mathrm{CD} 8^{+}$and high regulatory $\mathrm{T}$ cells are associated with a worse prognosis in $\mathrm{HCC}$ $(102,103)$. In a recent study by Shen et al it was demonstrated that Treg level and function is related with TNM stages in HCC patients and that SDF-1 may be responsible for the increased recruitment of Tregs to HCC tumor sites (104).

Th17 cells are $\mathrm{CD}^{+}$lymphocytes producing IL-17. Recently, they both have been found with increased frequencies within certain tumors (105). However, the relationship between Th17 cells and tumor immunopathology has been controversial $(106,107)$. In HCC, Th17 cells have been found in increased numbers within tumors and correlate with poor survival and increased postoperative recurrence, indicating that Th17 cells and IL-17 may promote tumor progression in HCC (108).

Endothelial cells. Endothelial cells play an essential role in blood vessel formation and its migration contributes to the creation of the tumor neovasculature. Endothelial cells in HCC tissues and normal tissues have molecular and functional differences. They express a variety of angiogenic receptors, including vascular endothelial growth factor receptors (VEGFR), epidermal growth factor homology domains-2 (Tie-2), epidermal growth factor receptor (EGFR), platelet-derived growth factor receptor (PDGFR) and C-X-C chemokine receptors (CXCRs). Several signaling pathways connected with survival, proliferation, mobilization and invasion of endothelial cells are regulated by the interaction between ligands and their corresponding receptors (109-112). Moreover, tumor-associated endothelial cells have a high expression of TGF- $\beta 1$ and CD105. TGF- $\beta 1$ plays a function of chemo-attractant for CD105 expressing endothelial cells and promotes tumor angiogenesis (113). Of note, it has been shown that $\mathrm{CD} 105^{+}$endothelial cells from $\mathrm{HCC}$, had features of increased angiogenesis activity with higher resistance to chemotherapeutic agents and to angiogenesis inhibitors (114).

Hepatoma cells. Hepatoma cells are not just passive observers of the tumor microenvironment because it has been suggested 
that they directly alter the surrounding milieu. Hepatoma cells are able to produce VEGF, PDGF, TGF- $\beta$, or monocyte colony stimulating factor (MCSF) leading to the recruitment and the activation of CAFs, TAMs, and endothelial cells $(113,115,116)$. Hepatoma cells can also inhibit differentiation and maturation of DCs by down-regulation of protein kinase C $\beta$ II expression and an increase in regulatory $\mathrm{T}$ cell production $(117,118)$. Another study shows that expression of glypican-3 on the hepatoma cell membrane is involved in macrophage recruitment (119).

Extracellular matrix. ECM includes the interstitial matrix and the basement membrane and is composed of many different glycoproteins, proteoglycans and hyaluronan (HA). The main roles of proteoglycans are to maintain the structural framework of the tissue and to store growth factors within the ECM. Heparan sulfate, chondroitin sulfate, and keratan sulfate are the major types of proteoglycans in the ECM. Of these, heparan sulfate proteoglycans (HSPGs) are known to play an important role in the pathogenesis of $\mathrm{HCC}$ as key growth factors such as FGF, HGF, PDGF, and VEGF are either stored in HSPGs or utilize HSPGs as co-receptors for binding to their tyrosine kinase receptors $(80,120,121)$. Several previous studies have shown that the heparin-degrading endosulfatases, sulfatase 1 (SULF1) and sulfatase 2 (SULF2), play important roles in modulating these heparin-binding growth signaling pathways $(122,123)$. Although SULF1 and SULF2 are structurally very similar, they play an opposite role in FGF signaling and its downstream AKT/mitogenactivated protein kinase pathway. Particularly, desulfation of co-receptor type HSPGs, SULF1-dependent, inhibits binding of the growth factor to its receptor, abrogating growth factor signaling and producing a tumor suppressing effect. Desulfation of HSPGs, SULF2-dependent, releases growth factors from the storage subtype of HSPGs and increases binding of growth factors to their receptors, leading to the activation of growth signaling $(122,124,125)$. A heparan sulfate mimetic, PI-88, synthesized for targeting heparanases in cancer, has been shown to inhibit SULFs activity and its safety and efficacy, as an adjuvant therapy for hepatocellular carcinoma after curative resection, was shown recently in a phase II clinical trial $(126,127)$. Several cell surface adhesion receptors and various ECM components (such as fibronectin, laminin, collagens, and elastin) are involved in extensive and complicated interactions through chemotaxis. Collagens are the most abundant protein in the ECM and provide a structural support for cells. As mentioned above, myofibroblasts/activated HSCs are the main source of collagen production in the HCC stroma $(128,129)$. Collagens also promote cell migration and proliferation in HCC. Let-7g, a known tumor suppressor miRNA, down-regulates COL1A2 and inhibits HCC cell migration and growth (130). Laminin is an important ECM protein involved in various biological activities, including assembly of the basement membrane, cell attachment, cell migration, cell growth and differentiation, and angiogenesis (131). Of the different subtypes of laminins, laminin-5 is expressed in HCC nodules, and its expression is associated with the metastatic phenotype of HCC (132). Moreover, Laminin-5 (Ln-5), together with TGF- $\beta 1$, was reported to promote epithelial to mesenchymal transition (133). Integrins are surface receptor proteins that mediate cell-matrix and cell-cell adhesion (134). The overexpression of $\beta 1$ integrin inhibits HCC cell proliferation by preventing Skp-2 dependent degradation of p27 via PI3K pathways (135). On the other hand, the overexpression of $\alpha 3 \beta 1$ and $\alpha 6 \beta 4$ integrin is associated with increased migration and invasion of HCC cells in an Ln-5 dependent condition (136-139).

Cytokines. The liver hosts many cell types that are susceptible to the actions of cytokines. Hepatocytes bear a variety of cytokine receptors such as IL-1, TNF- $\alpha$, and IL-6. Non-parenchymal cells, such as the resident liver macrophages (Kupffer cells), not only synthesize many cytokines, but the cytokine environment can also affect the actions of these immune cells. Liver sinusoidal endothelial cells are also targets and producers of various cytokines. Mounting evidence indicates the involvement of cytokines in hepatocarcinogenesis.

IL-6 is produced by Kupffer cells at high levels in response to hepatocyte death and thus it contributes to compensatory hepatocyte proliferation (140). Several studies investigated the interaction between IL- 6 and HBV. It has been shown that HBx can induce IL-6 release in HBV infected patients (141). In addition, HBx induced an increase in IL-6 transactivation (142). Indeed, $\mathrm{HBx}$ may play a role in hepatic inflammation and disease by up-regulating IL-6, leading to cirhossis and HCC (143). Serum IL-6 is increased in cirrhosis and high serum IL-6 is associated with increased risk for HCC and a poor prognosis in patients with HCC (144-146). It is a key cytokine, encouraging cancer cell proliferation while also inhibiting their apoptosis through activation of signal transducer and activator of transcription 3 (Stat3) (147). IL-6 signaling can also influence T cell subset differentiation, particularly in the presence of other cy tokines such as TGF- $\beta$ (148). Estrogen suppresses IL-6 production in Kupffer cells, partly explaining the gender discrepancy in HCC development (149). Moreover, it has been recently shown that IL-6 is a link between obesity and HCC as increased expression of IL-6 and TNF in obese mice leads to the activation of the IL-6 signaling pathway via the downstream STAT3 and ERK pathways, thus promoting tumorigenesis in the liver (150). Some studies have correlated changes in cytokine expression with HCC metastasis and/or recurrence. In a rat model, IL- 6 has been implicated in HCC metastasis, as highly metastatic HCC (metastatic to the abdominal cavity) has been shown to release more IL-6 in serum (151). Exogenous addition of IL-6 did not affect primary tumor formation but did affect the metastatic potential of tumor cells when compared with tumor cells expressing endogenous IL-6 (151). Furthermore, Coskun et al showed that in breast cancer patients, higher serum levels of IL- 6 could be used to distinguish primary or metastatic liver tumors from benign HCC lesions (152). Studies focusing on the association between IL-6 polymorphisms and HCC risk are still controversial, further studies are warrented to clarify these differing findings (153-155).

TNF- $\alpha$ is produced by Kupffer cells and other immune cells in response to tissue injury. It modulates NF- $\mathrm{BB}$ and Akt pathways and is involved in several tumor models $(37,156,157)$. It is associated with an increase in cell cycle progression and oxidative stress through the formation of 8-oxo-deoxyguanosine, an established marker of DNA damage associated with chronic hepatitis in human livers (158). Cytokine stimulation of TNF- $\alpha$, IL-1 $\beta$, or IL-18 has also been shown to induce expression of TRAIL in HCC cell lines (HepG2, Hep3B, Huh7). The expression of TRAIL on the HCC cell surface might contribute to tumor cell immune evasion by inducing apoptosis of activated human lymphocytes (159). Studies on TNF- $\alpha$ expression are still contro- 
versial, 2 reported high levels in HCC patients, especially those with recurrence $(160,161)$. In addition, the levels of the TNF- $\alpha$ Rs, TNF- $\alpha$ RI and TNF- $\alpha$ RII, were higher in HCC patients when compared with healthy individuals (162). However, in other studies, TNF- $\alpha$ levels were lower in HCC tumor tissue versus the tissue surrounding the tumor and in $\mathrm{HCC}$ patients versus healthy individuals $(163,164)$. In a study by Kakumu et al TNF- $\alpha$ Rs correlated with disease progression and IFN- $\alpha$ treatment did not affect their level (162). Regardin TNF- $\alpha$ polymorphism, the TNF- $\alpha$ (-308) SNP (single nucleotide polymorphisms) in the promoter region of the gene, which includes TNF- $\alpha 1$ (-308G) and TNF- $\alpha 2$ (-308A) alleles, is associated with cancer susceptibility and induced expression of TNF- $\alpha(153,165-167)$.

IL-1 is a pro-inflammatory cytokine that promotes MyD88 adaptor protein-dependent compensatory proliferation of hepatocytes (168). IL-1 also promotes HSC proliferation, activation, and transdifferentiation into the myofibroblastic phenotype in addition to activating HSCs to produce and activate MMPs, particularly MMP-9 (169). As mentioned, IL-1 $\beta$ has also been shown to induce expression of TRAIL in HCC cell lines (HepG2, Hep3B, Huh7) (159). In HCC patients, proinflammatory IL-1 $\beta$ was shown to be elevated compared with healthy individuals (160). However, in the analysis performed by Bortolami et al IL-1 $\beta$ mRNA was lower in tumors versus the tissue microenvironment (163). Polymorphism analyses of proinflammatory IL-1 $\beta$ related to hepatotropic viruses infection (HCV and HBV) have been reported, suggesting that IL-1 $\beta$ polymorphism may be a genetic marker for the development of hepatitis-related HCC (170-172).

IL-10 expression is, among the many anti-inflammatory cytokines, the most studied with regard to HCC. Several groups have shown that IL-10 is highly expressed in HCC tumors and individuals with HCC versus non-tumorous-surrounding tissue controls or healthy cohorts $(162,164,173-175)$. These studies suggest that increases in IL-10 and perhaps other Th2 cytokines correlate with progression. The clinical significance of postoperative IL-10 levels in patients with HCC resection was tested by Chau et al (176). They demonstrated how IL-10 levels were significantly higher in HCC than in healthy individuals and how patients with high IL-10 had a worse disease-free survival. A multivariate analysis implied that IL-10 might be a predictor of the postresection outcome of HCC patients (176). The association between IL-10 and the risk for developing HCC is still not clear (153,166,177-179). In a HCC mouse model, high angiogenic activity was associated with attenuated lymphocyte extravasation and correlated with the expression of anti-inflammatory IL-10 (109). Budhu et al analysed the tumor microenvironment in HCC metastasis from patients with HBV-positive metastatic HCC and found that a dominant, Th2-like cytokine profile (IL-4, IL-8, IL-10, and IL-5) and a decrease in Th1-like cytokines (IL-1 $\alpha$, IL-1 $\beta$, IL-2, IL-12p35, IL-12p40, IL-15, TNF- $\alpha$, and IFN- $\gamma$ ) was associated with the metastatic phenotype (180).

IL-12 plays a tumor suppressor role as it induces the production of interferon- $\gamma$ from NK cells or naïve T cells, promotes helper $\mathrm{T}$ cell differentiation, enhances cell-mediated immune responses, and activates cytotoxic lymphocytes (181). This effect is supposed to be mediated by the activation of tumor specific cytotoxic T lymphocytes and NK cells, and inhibition of angiogenesis (181). High level of IL-12 has been found in HCC patients (173). In a mouse model, intra-tumoral injection of IL-12 gene therapy induced lymphocyte infiltration into the tumor and inhibited tumor growth and angiogenesis $(96,182)$. However, the clinical use of IL-12 is limited due to the severe systemic toxicity resulting from high interferon- $\gamma$ levels in large doses and the minimal efficacy of low doses $(183,184)$.

IL-17 is produced by Th17 cells. Previous studies have shown that IL-17 is related to tumor progression via effects on immune cells, vascular endothelial cells and stromal cells $(108,185)$. In a recent study by $\mathrm{Gu}$ et $\mathrm{al}$ it has been suggested that the IL-17-mediated tumor-promoting role involved a direct effect on tumor cells through IL-6 induction by activating the AKT pathway; IL-6 in turn activated JAK2/STAT3 and up-regulated pro-invasive factors (IL-8, MMP-2, and VEGF both in vitro and in vivo) (186).

Growth-factors. TGF- $\beta$ exerts an indispensible and complex role in carcinogenesis and progression of tumors and particularly in liver fibrogenesis and hepatocarcinogenesis (187-189). It is up-regulated in HCC tissues and peri-neoplastic stroma (189). In HCC pathogenesis TGF- $\beta$ has a dual role. In the premalignant state it plays as a tumor suppressor through anti-proliferative effects and activation of apoptosis signals. The inhibition of cell proliferation is mediated by the mobilization of cyclin-dependent kinase inhibitors and suppression of c-Myc while the proapoptotic mechanisms of TGF- $\beta 1$ are mediated by down-regulation of anti-apoptotic proteins $(187,190)$. The tumor suppressor effect of TGF- $\beta$ acts also through the suppression of tumor stroma mitogens and tumorigenic inflammation (187). In addition, a study by Murata et al reported that TGF- $\beta$ suppressed viral RNA replication and protein expression from the HCV replicon and was also associated with a Smad-dependent cellular growth arrest (191). However, TGF- $\beta$ may function to enhance tumorigenicity and plays as an oncogenic growth factor via several different mechanisms (187). Matsuzaki et al and Murata et al showed, respectively, that HBx and HCV could shift hepatocytic TGF- $\beta$ signaling from the tumor-suppressive pSmad3C pathway to the oncogenic pSmad3L pathway through the activation of c-Jun N-terminal kinase (JNK) $(192,193)$. Sohn et al proposed that promoter methylation of tristetrapolin (TTP), a negative post-transcriptional regulator of C-Myc, shifts TGF- $\beta 1$ signaling in HCC tumorigenesis (194). Moreover, TGF- $\beta 1$ increases migration, vascular invasion (via $\alpha 3$ integrin expression), angiogenesis (via VEGF production) and metastasis (via connective tissue growth factor) (71,195-199). TGF- $\beta$ is also involved in the EMT through the down-regulation of E-cadherin and the up-regulation of Snail and the PDGF signaling pathway $(133,200,201)$. In a recent study, Wang et al reported that exposure of hepatocytes to TGF- $\beta 1$ increases miR-181b expression, which promotes cell growth, survival, migration and invasion of HCC cells (202). Similarly, TGF- $\beta$ induces miR-23a, 27a, and 24, which promotes growth and survival of HCC cells (203). Okumoto et al studied the relationship of plasma TGF- $\beta$ to anti-tumor immunity and prognosis. HCC patients with high TGF- $\beta$ concentration had a shorter survival period than those with concentrations below that of healthy individuals. Therefore, the concentration of TGF- $\beta$ was shown to be a predictor of outcome of patients with unresectable HCC (204). Single nucleotide polymorphism studies show that TGF- $\beta$ SNPs may be associated with reduced risk of developing viral hepatitis-mediated HCC but further studies are needed to clarify this association $(153,179,205-207)$. 
Other growth factors play important roles in HCC pathogenesis. FGFs are involved in angiogenesis, tissue regeneration and wound healing $(208,209)$. It has been found that aberrant expression of FGFs promotes HCC and endothelial cell proliferation through the activation of downstream Erk and AKT pathways (124) and facilitates invasion and metastasis of HCC $(210,211)$. HGF is expressed in hepatic stellate cells or myofibroblasts and is thought to be a mediator of tumorstromal interactions through which myofibroblasts increase the proliferation and invasion of HCC cells (121). The HGF ligand exerts its effect by binding the high-affinity tyrosine kinase receptor c-MET, which is predominantly expressed on the surface of epithelial and endothelial cells. c-MET overexpression, is observed in $20-48 \%$ of HCC samples (212-214). Deregulation of c-MET is associated with various molecular-genetic factors, and overexpression has been linked with decreased 5-year survival in patients with HCC (215). Moreover, a c-MET-regulated expression signature defines a subset of HCC in humans; these patients have a poor prognosis and an aggressive phenotype (216). PDGF plays an important role in the trans-differentiation of HSC into myofibroblast-like cells, thus stimulating fibrogenesis in the liver and increasing cell proliferation. It has been showed by Campbell et al that overexpression of PDGFC in the liver of the transgenic mouse results in HSC activation, proliferation, tissue fibrosis and subsequent development of hepatocellular carcinoma through the activation of the ERK-1/-2 and PKB/Akt signaling pathways (80). PDGF is also involved in neoangiogenesis, as it is believed to stabilize new blood vessels (217). Angiogenesis is a critical step in HCC progression and the VEGF is a major growth factor that stimulates angiogenesis in normal and tumor tissues (218). Overexpression of VEGF may be induced by the hypoxic tumor environment (mediated by hypoxia-inducible factor 2-a), activation of EGFR and cyclo-oxygenase-2 signaling $(219,220)$. The inflammatory condition via $N F-\kappa B$ signaling pathway boosts VEGF expression that acts not only on the proliferation of endothelial cells in the vasculature but also on the proliferation of cancer cells expressing VEGF-A receptor through downstream Akt/mTOR signaling $(221,222)$. Increased VEGF and VEGF receptors (VEGFRs; which include VEGFR-1, -2 and -3) expression has been observed in HCC cell lines and tissues, as well as in the serum of patients with HCC (223-226). The hepatitis Bx antigen has also been associated with the up-regulation of VEGFR-3 (227). VEGF clearly has an important regulatory role in HCC. High levels of VEGF expression have been linked with HCC tumor grade, poor outcome after resection, disease recurrence, poor disease-free and overall survival, vascular invasion, and portal vein emboli (228-232).

Matrix metalloproteinases (MMPs). MMPs lead to tissue remodeling, inflammation, tumor cell growth, migration, invasion and metastasis in many cancers. They are major modulators of the tumor microenvironment, playing key roles in tumorigenesis (99,233-235). Different stromal and cancer cells produce various types of MMPs whose main subtypes are collagenases (MMP-1, -8, -13), gelatinases (MMP-2, -9), matrylisins (MMP-7, -26), membrane type MMPs (MMP-14, $-15,-16,-17,-24,-25)$ and stromelysins (MMP-3, -10, -11) (236). As MMPs are released in inactivated forms they should be first triggered to exert their effect. Twist 1, focal adhesion kinase (FAK), claudin-1, HBV X protein, plasmin, furin, or other MMPs are well recognised activator of MMPs function (237-240). The role of MMPs in the microenvironment is not only limited to its proteolytic activity on the surrounding stroma, but it is also involved in modulating cancer signaling pathways $(99,234,241)$. For example, Mitsiades et al reported that Fas ligand is cleaved by MMP-7 and is then unable to induce apoptosis connecting MMPs to the inhibition of apoptosis signals in tumor cells (242). It has been also demonstrated that MMPs are involved in the modulation of the inflammatory response by regulating inflammatory cytokines and chemokines, which promote cancer progression $(233,243,244)$. MMP-2, -9, and -14 are involved in VEGF bioavailability and angiogenesis in HCC $(245,246)$ and also activate the TGF- $\beta$ that is a key modulator of epithelial-mesenchymal transition in HCC (241). Moreover, TGF- $\beta 1$ reciprocally activates MMPs via miR-181b, that is up-regulated by TGF- $\beta 1$ and up-regulates MMP-2 and -9 promoting migration and invasion of HCC cells (202). High expression of MMP-9 is associated with activation of the PI3K/PTEN/AKT/mTOR pathways $(247,248)$, invasion and metastasis by cleaving the osteopontin precursor into an active form (249) and capsular infiltration (250). Recent evidence suggests that MMP-9, linked with lipocalin-2 or neutrophilassociated lipocalin (NGAL), may enhance its role in cancer development (251-254). Accordingly, our preliminary studies indicate that both mRNA transcript and protein levels of NGAL were higher in HCC than in normal liver tissue; furthermore a correlation between NGAL and MMP-9 in HCC has been shown (Pezzino FM, et al, 15th World Congress on Advances in Oncology and 13th International Symposium on Molecular Medicine, abs. 349, S67, 2010 and Candido S, et al, 15th World Congress on Advances in Oncology and 13th International Symposium on Molecular Medicine, abs. 343, S65, 2011).

Tissue inhibitors of metalloproteinases (TIMPs) are natural inhibitors of MMPs and play complex roles in preventing the excessive degradation of ECM and in regulating cell proliferation, apoptosis, angiogenesis and MMPs activation. The enzymatic activities of MMP and TIMP are tightly balanced. It has been shown that high expression of TIMP-1 suppresses the proliferative and invasive potential of HCC cell lines $(255,256)$ and that TIMP-3 is a negative regulator of MMPs able to inhibit tumor progression, invasion, and metastasis in HCC (257,258). Gene expression profiles showed that MMP-14, -1 and TIMP-1 are gene signatures linked to poor prognosis in HCC $(259,260)$.

Physical environment. Hypoxia enhances proliferation, angiogenesis, metastasis, chemo-, and radio-resistance of HCC. Increasing evidence suggests that hypoxia exerts profound effects on the development and evolution of the tumor microenvironment by regulating differentiation of both tumor and stromal cells. Hypoxia induced factor-1 (HIF-1) is a major transcription factor induced and activated during hypoxia environment (261). Hypoxia can also induce $\beta$-catenin overexpression and intracellular accumulation in four different HCC cell lines through down-regulation of the endogenous degradation machinery (262). Activation of the HIF-1 $\alpha$-regulated glycolysis was closely related to HCC metastasis via ENO1, a glycolysis-related gene (263). 


\section{Signaling pathways in HCC}

Several abnormal molecular signaling pathways are implicated in HCC development and sheding light on these mechanisms will improve the understanding of molecular hepatocarcinogenesis. In this respect, the most important elements are growth factors signaling pathways (VEGF, PDGF, EGF, HGF), the mitogenactivated protein kinase (MAPK), phosphatidylinositol-3 kinase (PI3K)/AKT/mammalian target of rapamycin and WNT/ $\beta$ catenin pathways (264). These signaling cascades are of interest from a therapeutic perspective, because targeting them may help to reverse, delay or prevent hepatocarcinogenesis.

The ERK/MAPK pathway (also known as the RAF/MEK/ ERK pathway) is a ubiquitous signal transduction pathway that regulates crucial cellular processes, including proliferation, differentiation, angiogenesis and survival (265). Importantly, the overexpression or activation of components of this pathway is believed to contribute to tumorigenesis, tumor progression and disease metastasis in a variety of solid tumors (266). The ERK/ MAPK pathway lies downstream of various growth factors described in HCC and it has been shown that it is constitutively activated in this type of tumor (267-274). Constitutive activation of the PI3K/AKT/mTOR signaling pathway has been firmly established as a major determinant of tumor cell growth and survival in a multitude of solid tumors (248). In HCC PI3K/AKT/ mTOR signaling pathway is overboosted by different mechanisms suggesting that it may play a critical role in the pathogenesis of HCC (275-278). Alterations of the WNT/ $\beta$-catenin pathway are an early carcinogenic event in the development of HCC (279). The accumulation of $\beta$-catenin stimulates the expression of genes involved in cell proliferation (for example, MYC, MYB, CJUN and CYCD1), angiogenesis, anti-apoptosis and the formation of extracellular matrix (229). Giles et al showed that $\beta$-catenin is frequently mutated in HCC and this leads to the accumulation and stabilization of this glycoprotein (280). Additionally, these mutations seem to be particularly common in HCCs associated with chronic HCV infection (280). Hoshida et al performed a gene expression profile analysis of $603 \mathrm{HCC}$ patients in an effort to define molecular drivers of the disease. Three subclasses of HCC were characterized, two of which showed either increased WNT pathway activity or increased MYC/AKT pathway activity. The mechanism through which WNT pathway activation may occur was determined to be mediated by TGF- $\beta$ (281).

\section{New therapeutic opportunities}

The basic rationale for targeting tumor-stromal interface is to suppress the effect of surrounding tissues or cell types that stimulate hepatocarcinogenesis, tumor progression, invasion, and metastasis while minimizing systemic toxicity by delivering drug effects specifically to tumors and their microenvironment. Current drugs mostly target the tumor-stromal interaction by inhibiting receptors and their downstream signaling pathways, thereby abolishing the cancer-promoting signaling provided by the tumor stroma rather than directly targeting specific components.

The TGF- $\beta$ receptor inhibitor (LY2109761) is a clarifying example of this therapeutical approach. It acts through inhibition of CAFs proliferation and consequently suppresses synthesis and release of connective tissue growth factor, reduces tumor cell growth, intravasation, and metastatic dissemination of HCC cells (199). Phase I clinical trials targeting TGF- $\beta$ signaling for the treatment of HCC have not yet been performed. The recombinant monoclonal antibodies, bevacizumab, cetuximab, ramucirumab, whose efficacy in HCC is under evaluation in clinical trials, represent important goals in terms of target therapies. However, the class of kinase inhibitors is showing to have great potential, as sorafenib, an oral multi-kinase inhibitor, is the most successful medication of this kind. It inhibits VEGFR-2/-3 and PDGFR as well as Raf kinase, disrupting tumor-stromal interactions and resulting in decreased cell proliferation and angiogenesis. The efficacy and safety of sorafenib have been demonstrated in phase III clinical trials, and it is currently the standard of care for patients with advanced stage HCC (282). Similarly, brivanib, which targets VEGFR-2 and FGFR, sunitinib, which targets PDGFR, VEGFR, C-KIT and FLT-3, erlotinib, which targets EGFR, linifanib, which targets VEGFR and PDGFR, which targets VEGFR-2, and PI-88, which targets heparanase as well as sulfatases, are now in phase III clinical trials for the treatment of HCC.

The generation of tumor-associated fibronectin isoforms allows the development of specific ligands to be used for selective delivery of therapeutic agents (283). Additionally, Liu $e t$ al and WeiXing et al showed that targeting HIF-1 might be used as an effective gene therapy for HCC $(284,285)$.

\section{Conclusions}

Liver cancer is an intersting model to investigate the relationship between tumor microenvironment and tumor development. Improving the knowledge on this relationship may be crucial for the design of novel molecular targets. In this critical review of the literature, immune-mediate and/or viruses-related molecular mechanisms have been hypothesized as responsible for liver cancer development. The elucidation of these mechanisms regulating the interlink among HCC microenvironment components, comprising cellular elements, cytokines, growth factors and several proteins along with matrix metalloproteinases, is expected to contribute strongly to identifying the altered signaling pathways which are suitable targets for therapy. Growth factor and/ or matrix metalloproteinase inhibitors and immunomodulator drugs may represent a future prospective for the treatment of HCC. Accordingly, targeting tumor-stromal interface should also be considered in the therapeutic strategy.

\section{Acknowledgements}

This work was supported in part by MIUR-PRIN 2008 grant.

\section{References}

1. Mbeunkui F and Johann DJ: Cancer and the tumor microenvironment: a review of an essential relationship. Cancer Chemother Pharmacol 63: 571-582, 2009.

2. Witz IP and Levy-Nissenbaum O: The tumor microenvironment in the post-PAGET era. Cancer Lett 242: 1-10, 2006.

3. Balkwill $F$ and Mantovani A: Inflammation and cancer: back to virchow? Lancet 357: 539-545, 2001.

4. Finch CE and Crimmins EM: Inflammatory exposure and historical changes in human life-spans. Science 305: 1736-1739, 2004.

5. Mantovani A, Allavena P, Sica A and Balkwill F. Cancer-related inflammation. Nature 454: 436-444, 2008. 
6. Balkwill F, Charles KA and Mantovani A: Smoldering and polarized inflammation in the initiation and promotion of malignant disease. Cancer Cell 7: 211-217, 2005.

7. Koehne $\mathrm{CH}$ and Dubois RN: COX-2 inhibition and colorectal cancer. Semin Oncol 31: 12-21, 2004.

8. Flossmann E and Rothwell PM: Effect of aspirin on long-term risk of colorectal cancer: consistent evidence from randomised and observational studies. Lancet 369: 1603-1613, 2007.

9. Jemal A, Siegel R, Ward E, Hao Y, Xu J and Thun MJ: Cancer statistics, 2009. CA Cancer J Clin 59: 225-249, 2009.

10. Bruix J, Boix L, Sala M and Llovet JM: Focus on hepatocellular carcinoma. Cancer Cell 5: 215-219, 2004.

11. Amann T, Bataille F, Spruss T, Muhlbauer M, Gabele E Scholmerich J, Kiefer P, Bosserhoff AK and Hellerbrand C: Activated hepatic stellate cells promote tumorigenicity of hepatocellular carcinoma. Cancer Sci 100: 646-653, 2009.

12. Mohla S and Witz IP: The 5th International Conference on Tumor Microenvironment: Progression, Therapy and Prevention Versailles, France, October 20-24, 2009: conference summary. Cancer Microenviron 3: 1-5, 2010.

13. De Wever O, Demetter P, Mareel M and Bracke M: Stromal myofibroblasts are drivers of invasive cancer growth. Int J Cancer 123 2229-2238, 2008.

14. Xing F, Saidou J and Watabe K: Cancer associated fibroblasts (CAFs) in tumor microenvironment. Front Biosci 15: 166-179, 2010.

15. Anzola M: Hepatocellular carcinoma: role of hepatitis B and hepatitis $\mathrm{C}$ viruses proteins in hepatocarcinogenesis. J Viral Hepat 11: 383-393, 2004

16. Donato F, Boffetta P and Puoti M: A meta-analysis of epidemiological studies on the combined effect of hepatitis $\mathrm{B}$ and $\mathrm{C}$ virus infections in causing hepatocellular carcinoma. Int J Cancer 75 : 347-354, 1998

17. Brechot C, Jaffredo F, Lagorce D, Gerken G, Meyer zum Buschenfelde K, Papakonstontinou A, Hadziyannis S, Romeo R, Colombo M, Rodes J, Bruix J, Williams R and Naoumov N: Impact of HBV, HCV and GBV-C/HGV on hepatocellular carcinomas in Europe: results of a European concerted action. J Hepatol 29: 173-183, 1998.

18. Di Bisceglie AM: Hepatitis C. Lancet 351: 351-355, 1998.

19. Zhang JY, Dai M, Wang X, Lu WQ, Li DS, Zhang MX, Wang KJ, Dai LP, Han SG, Zhou YF and Zhuang H: A case-control study of hepatitis $\mathrm{B}$ and $\mathrm{C}$ virus infection as risk factors for hepatocellular carcinoma in Henan, China. Int J Epidemiol 27: 574-578, 1998.

20. Sun CA, Farzadegan H, You SL, Lu SN, Wu MH, Wolfe L, Hardy W, Huang GT, Yang PM, Lee $\mathrm{H}$ and Chen CJ: Mutual confounding and interactive effects between hepatitis $\mathrm{C}$ and hepatitis B viral infections in hepatocellular carcinogenesis: a population-based case-control study in Taiwan. Cancer Epidemiol Biomarkers Prev 5: 173-178, 1996.

21. Tsai JF, Jeng JE, Ho MS, Chang WY, Hsieh MY, Lin ZY and Tsai JH: Effect of hepatitis C and B virus infection on risk of hepatocellular carcinoma: a prospective study. Br J Cancer 76 : 968-974, 2003

22. Grivennikov SI, Greten FR and Karin M: Immunity, inflammation, and cancer. Cell 140: 883-899, 2010

23. Rapicetta M, Ferrari C and Levrero M: Viral determinants and host immune responses in the pathogenesis of HBV infection. J Med Virol 67: 454-457, 2002

24. Rehermann B: Intrahepatic T cells in hepatitis B: viral control versus liver cell injury. J Exp Med 191: 1263-1268, 2000.

25. Guidotti LG, Rochford R, Chung J, Shapiro M, Purcell R and Chisari FV: Viral clearance without destruction of infected cells during acute HBV infection. Science 284: 825-829, 1999

26. Kakimi K, Lane TE, Wieland S, Asensio VC, Campbell IL, Chisari FV and Guidotti LG: Blocking chemokine responsive to gamma-2/interferon (IFN)-gamma inducible protein and monokine induced by IFN-gamma activity in vivo reduces the pathogenetic but not the antiviral potential of hepatitis B virus-specific cytotoxic T lymphocytes. J Exp Med 194: 1755-1766, 2001.

27. Koike K: Hepatocarcinogenesis in hepatitis viral infection: lessons from transgenic mouse studies. J Gastroenterol 37: 55-64, 2002.

28. Freeman AJ, Marinos G, Ffrench RA and Lloyd AR: Immunopathogenesis of hepatitis $\mathrm{C}$ virus infection. Immunol Cell Biol 79: 515-536, 2001

29. Nakamura I and Imawari M: Cellular immune response in $\mathrm{HCV}$ infection. J Gastroenterol 35: 881-889, 2000.
30. Krawczynski K, Alter MJ, Tankersley DL, Beach M, Robertson BH, Lambert S, Kuo G, Spelbring JE, Meeks E, Sinha S and Carson DA: Effect of immune globulin on the prevention of experimental hepatitis C virus infection. J Infect Dis 173: 822-828, 1996.

31. Gomez J, Martell M, Quer J, Cabot B and Esteban JI: Hepatitis C viral quasispecies. J Viral Hepat 6: 3-16, 1999.

32. Ngui SL, Hallet R and Teo CG: Natural and iatrogenic variation in hepatitis B virus. Rev Med Virol 9: 183-209, 1999.

33. Bertoletti A, Sette A, Chisari FV, Penna A, Levrero M, De Carli M, Fiaccadori F and Ferrari C: Natural variants of cytotoxic epitopes are T-cell receptor antagonists for antiviral cytotoxic $\mathrm{T}$ cells. Nature 369: 407-410, 1994

34. Lanzavecchia A: Understanding the mechanisms of sustained signaling and T cell activation. J Exp Med 185: 1717-1719, 1997.

35. Sloan-Lancaster J, Evavold BD and Allen PM: Induction of T-cell anergy by altered T-cell-receptor ligand on live antigenpresenting cells. Nature 363: 156-159, 1993.

36. Nakamoto Y, Guidotti LG, Kuhlen CV, Fowler P and Chisari FV: Immune pathogenesis of hepatocellular carcinoma. J Exp Med 188: 341-350, 1998.

37. Karin M, Lawrence $\mathrm{T}$ and Nizet V: Innate immunity gone awry: linking microbial infections to chronic inflammation and cancer. Cell 124: 823-835, 2006.

38. Hussain SP, Hofseth LJ and Harris CC: Radical causes of cancer. Nat Rev Cancer 3: 276-285, 2003.

39. Hofseth LJ, Saito S, Hussain SP, Espey MG, Miranda KM, Araki Y, Jhappan C, Higashimoto Y, He P, Linke SP, Quezado MM, Zurer I, Rotter V, Wink DA, Appella E and Harris CC: Nitric oxide-induced cellular stress and p53 activation in chronic inflammation. Proc Natl Acad Sci USA 100: 143-148, 2003

40. Hagen TM, Huang S, Curnutte J, Fowler P, Martinez V, Wehr CM, Ames BN and Chisari FV: Extensive oxidative DNA damage in hepatocytes of transgenic mice with chronic active hepatitis destined to develop hepatocellular carcinoma. Proc Natl Acad Sci USA 91: 12808-12812, 1994.

41. Forgues M, Difilippantonio MJ, Linke SP, Ried T, Nagashima K, Feden J, Valerie K, Fukasawa K and Wang XW: Involvement of $\mathrm{Crm} 1$ in $\mathrm{HBx}$-induced aberrant centriole replication and abnormal mitotic spindles. Mol Cell Biol 23: 5282-5292, 2003.

42. Kim YC, Song KS, Yoon G, Nam MJ and Ryu WS: Activated ras oncogene collaborates with $\mathrm{HBx}$ gene of hepatitis B virus to transform cells by suppressing HBx-mediated apoptosis. Oncogene 20: 16-23, 2001

43. Yoshida T, Hanada T, Tokuhisa T, Kosai K, Sata M, Kohara M and Yoshimura A: Activation of STAT3 by the hepatitis C virus core protein leads to cellular transformation. J Exp Med 196: 641-653, 2002

44. Wang W, Budhu A, Forgues M and Wang XW: Temporal and spatial control of nucleophosmin by the Ran-Crm1 complex in centrosome duplication. Nat Cell Biol 7: 823-830, 2005.

45. Large MK, Kittlesen DJ and Hahn YS: Suppression of host immune response by the core protein of hepatitis $C$ virus: possible implications for hepatitis C virus persistence. J Immunol 162: 931-938, 1999.

46. You LR, Chen CM and Lee YHW: Hepatitis $C$ virus core protein enhances NF- $\mathrm{BB}$ signal pathway triggering by lymphotoxinbeta receptor ligand and tumor necrosis factor alfa. J Virol 73: 1672-1681, 1999

47. Lee CH, Choi YH, Yang SH, Lee CW, Ha SJ and Sung YC: Hepatitis $\mathrm{C}$ virus core protein inhibits interleukin 12 and nitric oxide production from activated macrophages. Virology 279: 271-279, 2001.

48. Wu CG, Budhu A, Chen S, Zhou X, Popescu NC, Valerie K and Wang XW: Effect of hepatitis $C$ virus core protein on the molecular profiling of human B lymphocyte. Mol Med 12: 47-53, 2006.

49. Chan-Fook C, Jiang WR, Clarke BE, Zitzmann N, Maidens C, McKeating JA and Jones IM: Hepatitis C virus glycoprotein E2 binding to CD81: the role of E1E2 cleavage and protein glycosylation in bioactivity. Virology 273: 60-66, 2000.

50. Reyes GR: The nonstructural NS5A protein of hepatitis $C$ virus: an expanding, multifunctional role in enhancing hepatitis $\mathrm{C}$ virus pathogenesis. J Biomed Sci 9: 187-197, 2002.

51. Carretero M, Gomez-Gonzalo M, Lara-Pezzi E, Benedicto I, Aramburu J, Martinez-Martinez S, Redondo J and LopezCabrera M: The hepatitis B virus X protein binds to and activates the $\mathrm{NH}(2)$-terminal trans-activation domain of nuclear factor of activated T cells-1. Virology 299: 288-300, 2002. 
52. Libra M,De Re V,De Vita S, Gasparotto D, Gloghini A, Rupolo M, Degan M, Marzotto A, Stivala F, Carbone A and Boiocchi M: Low frequency of bcl-2 rearrangement in HCV-associated nonHodgkin's lymphoma tissue. Leukemia 17: 1433-1436, 2003.

53. Libra M, De Re V, Gloghini A, Gasparotto D, Gragnani L, Navolanic PM, De Vita S, Mazzarino MC, Zignego AL, Carbone A and Boiocchi M: Detection of bcl-2 rearrangement in mucosaassociated lymphoid tissue lymphomas from patients with hepatitis C virus infection. Haematologica 89: 873-874, 2004.

54. Libra M, Indelicato M, De Re V, Zignego AL, Chiocchetti A, Malaponte G, Dianzani U, Nicoletti F, Stivala F, McCubrey JA and Mazzarino MC: Elevated serum levels of osteopontin in $\mathrm{HCV}$-associated lymphoproliferative disorders. Cancer Biol Ther 4: 1192-1194, 2005.

55. Libra M, Capello D, Gloghini A, Laura P, Berra E, Cerri M, Gasparotto D, Franca S, De Re V, Gaidano G and Carbone A: Analysis of aberrant somatic hypermutation (SHM) in nonHodgkin's lymphomas of patients with chronic HCV infection. J Pathol 206: 87-91, 2005.

56. Libra M, Gloghini A, De Re V, Rupolo M, Navolanic PM, Gasparotto D, Stivala F, Spina M, Boiocchi M and Carbone A: Aggressive forms of non-Hodgkin's lymphoma in two patients bearing coinfection of Epstein-Barr and hepatitis $\mathrm{C}$ viruses. Int J Oncol 26: 945-950, 2005

57. Libra M, Mangano K, Anzaldi M, Quattrocchi C, Donia M, Di Marco R, Signorelli S, Scalia G, Zignego AL, De Re V, Mazzarino MC and Nicoletti F: Analysis of interleukin (IL)-1beta IL-1 receptor antagonist, soluble IL-1 receptor type II and IL-1 accessory protein in $\mathrm{HCV}$-associated lymphoproliferative disorders. Oncol Rep 15: 1305-1308, 2006.

58. Libra M, Gloghini A, Malaponte G, Gangemi P, De Re V, Cacopardo B, Spandidos DA, Nicoletti F, Stivala F, Zignego AL and Carbone A: Association of $\mathrm{t}(14 ; 18)$ translocation with HCV infection in gastrointestinal MALT lymphomas. J Hepatol 49: 170-174, 2008

59. De Re V, Caggiari L, De Vita S, Mazzaro C, Lenzi M, Galli M, Monti G, Ferri C, Zignego AL, Gabrielli A, Sansonno D, Dammacco F, Libra M, Sacchi N, Talamini R, Spina M, Cannizzaro R, Guidoboni M and Dolcetti R: Genetic insights into the disease mechanisms of type II mixed cryoglobulinemia induced by hepatitis C virus. Dig Liver Dis 39: 65-71, 2007.

60. De Re V, Caggiari L, Simula MP, De Vita S, Mazzaro C, Lenzi M, Massimo GM, Monti G, Ferri C, Zignego AL, Gabrielli A, Sansonno D, Dammacco F, Libra M, Sacchi N, Talamini R, Spina M, Tirelli U, Cannizzaro R and Dolcetti R: Role of the HLA class II: HCV-related disorders. Ann NY Acad Sci 1107: 308-318, 2007.

61. De Re V, Caggiari L, Monti G, Libra M, Spina M, Dolcetti R, De Zorzi M, Racanelli V, Crovatto M and Toffoli G: HLA DR-DQ combination associated with the increased risk of developing human HCV positive non-Hodgkin's lymphoma is related to the type II mixed cryoglobulinemia. Tissue Antigens 75: 127-135, 2010.

62. Libra M, Polesel J, Russo AE, De Re V, Cinà D, Serraino D, Nicoletti F, Spandidos DA, Stivala F and Talamini R: Extrahepatic disorders of HCV infection: a distinct entity of B-cell neoplasia? Int J Oncol 36: 1331-1340, 2010.

63. Kalluri R and Zeisberg M: Fibroblasts in cancer. Nat Rev Cancer 6: 392-401, 2006.

64. Ostman A and Augsten M: Cancer-associated fibroblasts and tumor growth-bystanders turning into key players. Curr Opin Genet Dev 19: 67-73, 2009

65. Pietras K and Ostman A: Hallmarks of cancer: interactions with the tumor stroma. Exp Cell Res 316: 1324-1331, 2010.

66. Bhowmick NA, Neilson EG and Moses HL: Stromal fibroblasts in cancer initiation and progression. Nature 432: 332-337, 2004.

67. Orimo A, Gupta PB, Sgroi DC, et al: Stromal fibroblasts present in invasive human breast carcinomas promote tumor growth and angiogenesis through elevated SDF-1/CXCL12 secretion. Cell 121: 335-348, 2005.

68. Infante JR, Matsubayashi H, Sato N, Tonascia J, Klein AP, Riall TA, Yeo C, Iacobuzio-Donahue C and Goggins M: Peritumoral fibroblast SPARC expression and patient outcome with resectable pancreatic adenocarcinoma. J Clin Oncol 25: 319-325, 2007.

69. Mueller L, Goumas FA, Affeldt M, et al: Stromal fibroblasts in colorectal liver metastases originate from resident fibroblasts and generate an inflammatory microenvironment. Am J Pathol 171: $1608-1618,2007$.
70. Gaggioli C, Hooper S, Hidalgo-Carcedo C, Grosse R, Marshall JF, Harrington K and Sahai E: Fibroblast-led collective invasion of carcinoma cells with differing roles for RhoGTPases in leading and following cells. Nat Cell Biol 9: 1392-1400, 2007.

71. Fransvea E, Mazzocca A, Antonaci S and Giannelli G: Targeting transforming growth factor (TGF)-betaRI inhibits activation of betal integrin and blocks vascular invasion in hepatocellular carcinoma. Hepatology 49: 839-850, 2009.

72. Friedman SL, Roll FJ, Boyles J and Bissell DM: Hepatic lipocytes: the principal collagen-producing cells of normal rat liver. Proc Natl Acad Sci USA 82: 8681-8685, 1985.

73. Wynn TA: Cellular and molecular mechanisms of fibrosis. J Pathol 214: 199-210, 2008.

74. Bataller R and Brenner DA: Liver fibrosis. J Clin Invest 115: 209-218, 2005

75. Friedman SL: Hepatic stellate cells: protean, multifunctional, and enigmatic cells of the liver. Physiol Rev 88: 125-172, 2008.

76. Dubuisson L, Lepreux S, Bioulac-Sage P, Balabaud C, Costa AM, Rosenbaum $\mathrm{J}$ and Desmoulière A: Expression and cellular localization of fibrillin-1 in normal and pathological human liver. J Hepatol 34: 514-522, 2001.

77. Xia Y, Chen R, Song Z, Ye S, Sun R, Xue Q and Zhang Z: Gene expression profiles during activation of cultured rat hepatic stellate cells by tumoral hepatocytes and fetal bovine serum. J Cancer Res Clin Oncol 136: 309-321, 2010.

78. Sancho-Bru P, Juez E, Moreno M, et al: Hepatocarcinoma cells stimulate the growth, migration and expression of pro-angiogenic genes in human hepatic stellate cells. Liver Int 30: 31-41, 2010.

79. Eghbali-Fatourechi G, Sieck GC, Prakash YS, Maercklein P, Gores GJ and Fitzpatrick LA: Type I procollagen production and cell proliferation is mediated by transforming growth factor-beta in a model of hepatic fibrosis. Endocrinology 137: 1894-1903, 1996.

80. Campbell JS, Hughes SD, Gilbertson DG, et al: Platelet-derived growth factor $\mathrm{C}$ induces liver fibrosis, steatosis, and hepatocellular carcinoma. Proc Natl Acad Sci USA 102: 3389-3394, 2005.

81. Roderfeld M, Weiskirchen R, Wagner S, Berres ML, Henkel C, Grötzinger J, Gressner AM, Matern S and Roeb E: Inhibition of hepatic fibrogenesis by matrix metalloproteinase- 9 mutants in mice. FASEB J 20: 444-454, 2006.

82. Schulze-Krebs A, Preimel D, Popov Y, Bartenschlager R, Lohmann V, Pinzani M and Schuppan D: Hepatitis C virusreplicating hepatocytes induce fibrogenic activation of hepatic stellate cells. Gastroenterology 129: 246-258, 2005.

83. Martín-Vílchez S, Sanz-Cameno P, Rodríguez-Muñoz Y, Majano PL, Molina-Jiménez F, López-Cabrera M, MorenoOtero R and Lara-Pezzi E: The hepatitis B virus X protein induces paracrine activation of human hepatic stellate cells. Hepatology 47: 1872-1883, 2008.

84. Nitta T, Kim JS, Mohuczy D and Behrns KE: Murine cirrhosis induces hepatocyte epithelial mesenchymal transition and alterations in survival signaling pathways. Hepatology 48: 909-919, 2008.

85. Kluwe J, Pradere JP, Gwak GY, Mencin A, De Minicis S, Osterreicher $\mathrm{CH}$, Colmenero J, Bataller R and Schwabe RF: Modulation of hepatic fibrosis by c-Jun-N-terminal kinase inhibition. Gastroenterology 138: 347-359, 2010.

86. Moles A, Tarrats N, Fernandez-Checa JC and Mari M Cathepsins B and D drive hepatic stellate cell proliferation and promote their fibrogenic potential. Hepatology 49: 1297-1307, 2009.

87. Sokolovic A, Sokolovic M, Boers W, Elferink RP and Bosma PJ: Insulin-like growth factor binding protein 5 enhances survival of LX2 human hepatic stellate cells. Fibrogenesis Tissue Repair 3: $3,2010$.

88. Mantovani A, Bottazzi B, Colotta F, Sozzani S and Ruco L: The origin and function of tumor-associated macrophages. Immunol Today 13: 265-270, 1992

89. Bunt SK, Yang L, Sinha P, Clements VK, Leips J and Ostrand-Rosenberg S: Reduced inflammation in the tumor microenvironment delays the accumulation of myeloid-derived suppressor cells and limits tumor progression. Cancer Res 67: 10019-10026, 2007

90. Coussens LM, Tinkle CL, Hanahan D and Werb Z: MMP-9 supplied by bone marrow derived cells contributes to skin carcinogenesis. Cell 103: 481-490, 2000.

91. Mantovani A, Sozzani S, Locati M, Allavena P and Sica A: Macrophage polarization: tumor-associated macrophages as a paradigm for polarized M2 mononuclear phagocytes. Trends Immunol 23: 549-555, 2002. 
92. Mantovani A, Sica A, Allavena P, Garlanda C and Locati M Tumor-associated macrophages and the related myeloid-derived suppressor cells as a paradigm of the diversity of macrophage activation. Hum Immunol 70: 325-330, 2009.

93. Biswas SK and Mantovani A: Macrophage plasticity and interaction with lymphocyte subsets: cancer as a paradigm. Nat Immunol 11: 889-896, 2010

94. Gabrilovich DI and Nagaraj S: Myeloid-derived suppressor cells as regulators of the immune system. Nat Rev Immunol 9: $162-174,2009$

95. Movahedi K, Laoui D, Gysemans C, Baeten M, Stangè G, van den Bossche J, Mack M, Pipeleers D, In't Veld P, De Baetselier P and van Ginderachter JA: Different tumor microenvironments contain functionally distinct subsets of macrophages derived from Ly6C (high) monocytes. Cancer Res 70: 5728-5739, 2010.

96. Barajas M, Mazzolini G, Genove G, Bilbao R, Narvaiza I, Schmitz V, Sangro B, Melero I, Qian C and Prieto J: Gene therapy of orthotopic hepatocellular carcinoma in rats using adenovirus coding for interleukin 12. Hepatology 33: 52-61, 2001

97. Wu K, Kryczek I, Chen L, Zou W and Welling TH: Kupffer cell suppression of $\mathrm{CD}^{+} \mathrm{T}$ cells in human hepatocellular carcinoma is mediated by B7-H1/programmed death-1 interactions. Cancer Res 69: 8067-8075, 2009.

98. Ramaiah SK and Rittling S: Pathophysiological role of osteopontin in hepatic inflammation, toxicity, and cancer. Toxicol Sci 103: 4-13, 2008

99. Castellano G, Malaponte G, Mazzarino MC, Figini M, Marchese F, Gangemi P, Travali S, Stivala F, Canevari S and Libra M: Activation of the osteopontin/matrix metalloproteinase-9 pathway correlates with prostate cancer progression. Clin Cancer Res 14: 7470-7480, 2008.

100. Bui JD and Schreiber RD: Cancer immunosurveillance, immunoediting and inflammation: independent or interdependent processes? Curr Opin Immunol 19: 203-208, 2007.

101. Chen W, Jin W, Hardegen N,Lei KJ, Li L, Marinos N, McGrady G and Wahl SM: Conversion of peripheral $\mathrm{CD} 4{ }^{+} \mathrm{CD} 25^{-}$naive $\mathrm{T}$ cells to $\mathrm{CD} 4{ }^{+} \mathrm{CD} 25^{+}$regulatory $\mathrm{T}$ cells by TGF-beta induction of transcription factor Foxp3. J Exp Med 198: 1875-1886, 2003.

102. Fu J, Xu D, Liu Z, et al: Increased regulatory T cells correlate with CD8 T-cell impairment and poor survival in hepatocellular carcinoma patients. Gastroenterology 132: 2328-2339, 2007.

103. Gao Q, Qiu SJ, Fan J, Zhou J, Wang XY, Xiao YS, Xu Y, Li YW and Tang ZY: Intratumoral balance of regulatory and cytotoxic $\mathrm{T}$ cells is associated with prognosis of hepatocellular carcinoma after resection. J Clin Oncol 25: 2586-2593, 2007.

104. Shen X, Li N, Li H, Zhang T, Wang F and Li Q: Increased prevalence of regulatory $\mathrm{T}$ cells in the tumor microenvironment and its correlation with TNM stage of hepatocellular carcinoma. J Cancer Res Clin Oncol 136: 1745-1754, 2010.

105. Kryczek I, Banerjee M, Cheng P, Vatan L, Szeliga W, Wei S, Huang E, Finlayson E, Simeone D, Welling TH, Chang A, Coukos G, Liu R and Zou W: Phenotype, distribution, generation, and functional and clinical relevance of Th17 cells in the human tumor environments. Blood 114: 1141-1149, 2009.

106. Bronte V: Th17 and cancer: friends or foes? Blood 112: 214, 2008

107. Murugaiyan G and Saha B: Protumor vs antitumor functions of IL-17. J Immunol 183: 4169-4175, 2009.

108. Zhang JP, Yan J, Xu J, Pang XH, Chen MS, Li L, Wu C, Li SP and Zheng L: Increased intratumoral IL-17-producing cells correlate with poor survival in hepatocellular carcinoma patients. J Hepatol 50: 980-989, 2009.

109. Ryschich E, Lizdenis P, Ittrich C, et al: Molecular fingerprinting and autocrine growth regulation of endothelial cells in a murine model of hepatocellular carcinoma. Cancer Res 66 : 198-211, 2006

110. Amin DN, Hida K, Bielenberg DR and Klagsbrun M: Tumor endothelial cells express epidermal growth factor receptor (EGFR) but not ErbB3 and are responsive to EGF and to EGFR kinase inhibitors. Cancer Res 66: 2173-2180, 2006.

111. Rolny C, Nilsson I, Magnusson P, et al: Platelet-derived growth factor receptor beta promotes early endothelial cell differentiation. Blood 108: 1877-1886, 2006

112. Yu Q: The dynamic roles of angiopoietins in tumor angiogenesis. Future Oncol 1: 475-484, 2005.

113. Benetti A, Berenzi A, Gambarotti M, Garrafa E, Gelati M, Dessy E, Portolani N, Piardi T, Giulini SM, Caruso A, Invernici G, Parati EA, Nicosia R and Alessandri G: Transforming growth factor-beta1 and CD105 promote the migration of hepatocellular carcinoma-derived endothelium. Cancer Res 68: 8626-8634, 2008.
114. Xiong YQ, Sun HC, Zhang W, et al: Human hepatocellular carcinoma tumor-derived endothelial cells manifest increased angiogenesis capability and drug resistance compared with normal endothelial cells. Clin Cancer Res 15: 4838-4846, 2009.

115. Pietras K, Pahler J, Bergers G and Hanahan D: Functions of paracrine PDGF signaling in the proangiogenic tumor stroma revealed by pharmacological targeting. PLoS Med 5: e19, 2008

116. Zhu XD, Zhang JB, Zhuang PY, Zhu HG, Zhang W, Xiong YQ Wu WZ, Wang L, Tang ZY and Sun HC: High expression of macrophage colony stimulating factor in peritumoral liver tissue is associated with poor survival after curative resection of hepatocellular carcinoma. J Clin Oncol 26: 2707-2716, 2008.

117. Farren MR, Carlson LM and Lee KP: Tumor-mediated inhibition of dendritic cell differentiation is mediated by down regulation of protein kinase $C$ beta II expression. Immunol Res 46: 165-176, 2010.

118. Li L, Li SP, Min J and Zheng L: Hepatoma cells inhibit the differentiation and maturation of dendritic cells and increase the production of regulatory T cells. Immunol Lett 114: 38-45, 2007.

119. Takai H, Kato A, Kato C, Watanabe T, Matsubara K, Suzuki M and Kataoka $\mathrm{H}$ : The expression profile of glypican-3 and its relation to macrophage population in human hepatocellular carcinoma. Liver Int 29: 1056-1064, 2009.

120. Ogasawara S, Yano H, Iemura A, Hisaka T and Kojiro M: Expressions of basic fibroblast growth factor and its receptors and their relationship to proliferation of human hepatocellular carcinoma cell lines. Hepatology 24: 198-205, 1996.

121. Neaud V, Faouzi S, Guirouilh J, Le Bail B, Balabaud C, BioulacSage P and Rosenbaum J: Human hepatic myofibroblasts increase invasiveness of hepatocellular carcinoma cells: evidence for a role of hepatocyte growth factor. Hepatology 26: 1458-1466, 1997.

122. Uchimura K, Morimoto-Tomita M, Bistrup A, Li J, Lyon M, Gallagher J, Werb Z and Rosen SD: HSulf-2, an extracellular endoglucosamine-6-sulfatase, selectively mobilizes heparinbound growth factors and chemokines: effects on VEGF, FGF-1, and SDF-1. BMC Biochem 7: 2, 2006.

123. Wang S, Ai X, Freeman SD, Pownall ME, Lu Q, Kessler DS and Emerson CP Jr: QSulf1, a heparan sulfate 6-O-endosulfatase, inhibits fibroblast growth factor signalling in mesoderm induction and angiogenesis. Proc Natl Acad Sci USA 101: 4833-4838, 2004.

124. Lai JP, Chien JR, Moser DR, et al: hSulf1 sulfatase promotes apoptosis of hepatocellular cancer cells by decreasing heparinbinding growth factor signaling. Gastroenterology 126: 231-248, 2004

125. Lai JP, Sandhu DS, Yu C, et al: Sulfatase 2 up-regulates glypican 3, promotes fibroblast growth factor signaling, and decreases survival in hepatocellular carcinoma. Hepatology 47: 1211-1222, 2008

126. Hossain MM, Hosono-Fukao T, Tang R, Sugaya N, van Kuppevelt TH, Jenniskens GJ, Kimata K, Rosen SD and Uchimura K: Direct detection of HSulf-1 and HSulf-2 activities on extracellular heparan sulfate and their inhibition by PI-88 Glycobiology 20: 175-186, 2010.

127. Liu CJ, Lee PH, Lin DY, et al: Heparanase inhibitor PI-88 as adjuvant therapy for hepatocellular carcinoma after curative resection: a randomized phase II trial for safety and optimal dosage. J Hepatol 50: 958-968, 2009.

128. Faouzi S, Le Bail B, Neaud V, Boussarie L, Saric J, Bioulac-Sage P, Balabaud $\mathrm{C}$ and Rosenbaum J: Myofibroblasts are responsible for collagen synthesis in the stroma of human hepatocellular carcinoma: an in vivo and in vitro study. J Hepatol 30: 275-284, 1999.

129. Ooi LP, Crawford DH, Gotley DC, et al: Evidence that 'myofibroblast-like' cells are the cellular source of capsular collagen in hepatocellular carcinoma. J Hepatol 26: 798-807, 1997.

130. Ji J, Zhao L, Budhu A, Forgues M, Jia HL, Qin LX, Ye QH, Yu J, Shi X, Tang ZY and Wang XW: Let-7g targets collagen type I alpha 2 and inhibits cell migration in hepatocellular carcinoma. J Hepatol 52: 690-697, 2010.

131. Miner JH: Laminins and their roles in mammals. Microsc Res Tech 71: 349-356, 2008.

132. Giannelli G, Fransvea E, Bergamini C, Marinosci F and Antonaci S: Laminin-5 chains are expressed differentially in metastatic and nonmetastatic hepatocellular carcinoma. Clin Cancer Res 9: 3684-3691, 2003.

133. Giannelli G, Bergamini C, Fransvea E, Sgarra C and Antonaci S: Laminin-5 with transforming growth factor-betal induces epithelial to mesenchymal transition in hepatocellular carcinoma. Gastroenterology 129: 1375-1383, 2005. 
134. Silva R, D'Amico G, Hodivala-Dilke KM and Reynolds LE: Integrins: the keys to unlocking angiogenesis. Arterioscler Thromb Vasc Biol 28: 1703-1713, 2008.

135. Fu Y, Fang Z, Liang Y, Zhu X, Prins P, Li Z, Wang L, Sun L, Jin J, Yang Y and Zha X: Overexpression of integrin beta 1 inhibits proliferation of hepatocellular carcinoma cell SMMC-7721 through preventing Skp2-dependent degradation of $\mathrm{p} 27$ via PI3K pathway. J Cell Biochem 102: 704-718, 2007.

136. Carter WG, Kaur P, Gil SG, Gahr PJ and Wayner EA: Distinct functions for integrins alpha 3 beta 1 in focal adhesions and alpha 6 beta 4/bullous pemphigoid antigen in a new stable anchoring contact (SAC) of keratinocytes: relation to hemidesmosomes. J Cell Biol 111: 3141-3154, 1990.

137. Giannelli G, Bergamini C, Fransvea E, Marinosci F, Quaranta V and Antonaci S: Human hepatocellular carcinoma (HCC) cells require both alpha3betal integrin and matrix metalloproteinases activity for migration and invasion. Lab Invest 81: 613-627, 2001.

138. Bergamini C, Sgarra C, Trerotoli P, Lupo L, Azzariti A, Antonaci S and Giannelli G: Laminin-5 stimulates hepatocellular carcinoma growth through a different function of alpha6beta4 and alpha3beta1 integrins. Hepatology 46: 1801-1809, 2007.

139. Mizuno H, Ogura M, Saito Y, et al: Changes in adhesive and migratory characteristics of hepatocellular carcinoma (HCC) cells induced by expression of alpha3beta1 integrin. Biochim Biophys Acta 1780: 564-570, 2008.

140. Cressman DE, Greenbaum LE, De Angelis RA, Ciliberto G, Furth EE, Poli V and Taub R: Liver failure and defective hepatocyte regeneration in interleukin-6-deficient mice. Science 274 1379-1383, 1996.

141. Ohno H, Kaneko S, Lin Y, Kobayashi K and Murakami S: Human hepatitis B virus X protein augments the DNA binding of nuclear factor for IL-6 through its basic-leucine zipper domain. J Med Virol 58: 11-18, 1999.

142. Song IH, Binh VQ, Duy DN, Kun JF, Bock TC, Kremsner PG and Luty AJ: Serum cytokine profiles associated with clinical presentation in Vietnamese infected with hepatitis B virus. J Clin Virol 28: 93-103, 2003

143. Lee Y, Park US, Choi I, Yoon SK, Park YM and Lee YI: Human interleukin 6 gene is activated by hepatitis B virus-X protein in human hepatoma cells. Clin Cancer Res 4: 1711-1717, 1998.

144. Nakagawa H, Maeda S, Yoshida H, et al: Serum IL-6 levels and the risk for hepatocarcinogenesis in chronic hepatitis $\mathrm{C}$ patients: an analysis based on gender differences. Int J Cancer 125: 2264-2269, 2009.

145. Tilg H, Wilmer A, Vogel W, Herold M, Nölchen B, Judmaier G and Huber C: Serum levels of cytokines in chronic liver diseases. Gastroenterology 103: 264-274, 1992.

146. Wong VW, Yu J, Cheng AS, Wong GL, Chan HY, Chu ES, Ng EK, Chan FK, Sung JJ and Chan HL: High serum interleukin-6 level predicts future hepatocellular carcinoma development in patients with chronic hepatitis B. Int J Cancer 124: 2766-2770, 2009.

147. Yu H, Pardoll D and Jove R: STATs in cancer inflammation and immunity: a leading role for STAT3. Nat Rev Cancer 9: 798-809, 2009.

148. Littman DR and Rudensky AY: Th17 and regulatory T cells in mediating and restraining inflammation. Cell 140: 845-858, 2010.

149. Naugler WE, Sakurai T, Kim S, Maeda S, Kim K, Elsharkawy AM and Karin M: Gender disparity in liver cancer due to sex differences in MyD88-dependent IL-6 production. Science 317: 121-124, 2007.

150. Park EJ,LeeJH,Yu GY,He G, Ali SR,Holzer RG, OsterreicherCH, Takahashi $\mathrm{H}$ and Karin M: Dietary and genetic obesity promote liver inflammation and tumorigenesis by enhancing IL-6 and TNF expression. Cell 140: 197-208, 2010.

151. Reichner JS, Mulligan JA, Spisni R, Sotomayor EA, Albina JE and Bland KI: Effect of IL-6 overexpression on the metastatic potential of rat hepatocellular carcinoma cells. Ann Surg Oncol 5: 279-286, 1998

152. Coskun U, Bukan N, Sancak B, Gunel N, Ozenirler S, Unal A and Yucel A: Serum hepatocyte growth factor and interleukin-6 levels can distinguish patients with primary or metastatic liver tumors from those with benign liver lesions. Neoplasma 51 209-213, 2004.

153. Ben Ari Z, Mor E, Papo O, Kfir B, Sulkes J, Tambur AR Tur-Kaspa R and Klein T: Cytokine gene polymorphisms in patients infected with hepatitis B virus. Am J Gastroenterol 98: 144-150, 2003.

154. Giannitrapani L, Soresi M, Giacalone A, Campagna ME, Marasà M, Cervello M, Marasà S and Montalto G: IL-6 -174G/C polymorphism and IL-6 serum levels in patients with liver cirrhosis and hepatocellular carcinoma. OMICS 15: 183-186, 2011.
155. Park BL, Lee HS, Kim YJ, Kim JY, Jung JH, Kim LH and Shin HD: Association between interleukin 6 promoter variants and chronic hepatitis B progression. Exp Mol Med 35: 76-82, 2003.

156. Fausto N, Campbell JS and Riehle KJ: Liver regeneration. Hepatology 43: 45-53, 2006

157. Karin M: Nuclear factor-kappaB in cancer development and progression. Nature 441: 431-436, 2006.

158. Wheelhouse NM, Chan YS, Gillies SE, Caldwell H, Ross JA, Harrison DJ and Prost S: TNF-alfa induced DNA damage in primary murine hepatocytes. Int J Mol Med 12: 889-894, 2003.

159. Shiraki K, Yamanaka T, Inoue H, Kawakita T, Enokimura N Okano H, Sugimoto K, Murata K and Nakano T: Expression of TNF-related apoptosis-inducing ligand in human hepatocellular carcinoma. Int J Oncol 26: 1273-1281, 2005.

160. Huang YS, Hwang SJ, Chan CY, Wu JC, Chao Y, Chang FY and Lee SD: Serum levels of cytokines in hepatitis C-related liver disease: a longitudinal study. Zhonghua Yi Xue Za Zhi (Taipei) 62: 327-333, 1999.

161. Nakazaki H: Preoperative and postoperative cytokines in patients with cancer. Cancer 70: 709-713, 1992.

162. Kakumu S, Okumura A, Ishikawa T, Yano M, Enomoto A Nishimura H, Yoshioka K and Yoshika Y: Serum levels of IL-10, IL-15 and soluble tumor necrosis factor-alfa (TNF-alfa) receptors in type $\mathrm{C}$ chronic liver disease. Clin Exp Immunol 109: 458-463, 1997

163. Bortolami M, Venturi C, Giacomelli L, Scalerta R, Bacchetti S, Marino F, Floreani A, Lise M, Naccarato R and Farinati F: Cytokine, infiltrating macrophage and $\mathrm{T}$ cell-mediated response to development of primary and secondary human liver cancer. Dig Liver Dis 34: 794-801, 2002.

164.Zekri AR, Ashour MS, Hassan A, Alam El-Din HM, El Shehaby AM and Abu-Shady MA: Cytokine profile in Egyptian hepatitis $C$ virus genotype-4 in relation to liver disease progression. World J Gastroenterol 11: 6624-6630, 2005.

165. Ho SY, Wang YJ, Chen HL, Chen CH, Chang CJ, Wang PJ, Chen HH and Guo HR: Increased risk of developing hepatocellular carcinoma associated with carriage of the TNF2 allele of the -308 tumor necrosis factor- $\beta$ promoter gene. Cancer Causes Control 15: 657-663, 2004.

166. Heneghan MA, Johnson PJ, Clare M, Ho S, Harrison PM and Donaldson PT: Frequency and nature of cytokine gene polymorphisms in hepatocellular carcinoma in Hong Kong Chinese. Int J Gastrointest Cancer 34: 19-26, 2003.

167. Talaat RM, Esmail AA, Elwakil R, Gurgis AA and Nasr MI: Tumor necrosis factor-alpha -308G/A polymorphism and risk of hepatocellular carcinoma in hepatitis $\mathrm{C}$ virus-infected patients. Chin J Cancer 31: 29-35, 2012.

168. Akira S, Uematsu S and Takeuchi O: Pathogen recognition and innate immunity. Cell 124: 783-801, 2006.

169. Han YP, Zhou L, Wang J, Xiong S, Garner WL, French SW and Tsukamoto H: Essential role of matrix metalloproteinases in interleukin-1-induced myofibroblastic activation of hepatic stellate cell in collagen. J Biol Chem 279: 4820-4828, 2004.

170. Hirankarn N, Kimkong I, Kummee P, Tangkijvanich P and Poovorawan Y: Interleukin-1 $\beta$ gene polymorphism associated with hepatocellular carcinoma in hepatitis B virus infection. World J Gastroenterol 12: 776-779, 2006

171. Tanaka Y, Furuta T, Suzuki S, Orito E, Yeo AE, Hirashima N, Sugauchi F, Ueda R and Mizokami M: Impact of interleukin-1 $\beta$ genetic polymorphisms on the development of hepatitis $C$ virusrelated hepatocellular carcinoma in Japan. J Infect Dis 187: 1822-1825, 2003

172. Wang Y, Kato N, Hoshida Y, Yoshida H, Taniguchi H, Goto T, Moriyama M, Otsuka M, Shiina S, Shiratori Y, Ito Y and Omata M: Interleukin-1 $\beta$ gene polymorphisms associated with hepatocellular carcinoma in hepatitis $C$ virus infection. Hepatology 37: 65-71, 2003.

173. Kitaoka S, Shiota G and Kawasaki H: Serum levels of interleukin-10, interleukin-12 and soluble interleukin-2 receptor in chronic liver disease type C. Hepatogastroenterology 50: 1569-1574, 2003

174. Chia CS, Ban K, Ithnin H, Singh H, Krishnan R, Mokhtar S, Malihan N and Seow HF: Expression of interleukin-18, interferongamma and interleukin-10 in hepatocellular carcinoma. Immunol Lett 84: 163-172, 2002

175. Beckebaum S, Zhang X, Chen X, Yu Z, Frilling A, Dworacki G, Grosse-Wilde H, Broelsch CE, Gerken G and Cicinnati VR: Increased levels of interleukin-10 in serum from patients with hepatocellular carcinoma correlate with profound numerical deficiencies and immature phenotype of circulating dendritic cell subsets. Clin Cancer Res 10: 7260-7269, 2004. 
176. Chau GY, Wu CW, Lui WY, Chang TJ, Kao HL, Wu LH, King KL, Loong CC, Hsia CY and Chi CW: Serum interleukin-10 but not interleukin- 6 is related to clinical outcome in patients with resectable hepatocellular carcinoma. Ann Surg 231: 552-558, 2000.

177. Shin HD, Park BL, Kim LH, Jung JH, Kim JY, Yoon JH, Kim YJ and Lee HS: Interleukin 10 haplotype associated with increased risk of hepatocellular carcinoma. Hum Mol Genet 12: 901-906, 2003.

178. Nieters A, Yuan JM, Sun CL, Zhang ZQ, Stoehlmacher J, Govindarajan S and Yu MC: Effect of cytokine genotypes on the hepatitis B virus-hepatocellular carcinoma association. Cancer 103: 740-748, 2005.

179. Migita K, Miyazoe S, Maeda Y, Daikoku M, Abiru S, Ueki T, Yano K, Nagaoka S, Matsumoto T, Nakao K, Hamasaki K, Yatsuhashi H, Ishibashi $\mathrm{H}$ and Eguchi K: Cytokine gene polymorphisms in Japanese patients with hepatitis B virus infection-association between TGF- $\beta 1$ polymorphisms and hepatocellular carcinoma. J Hepatol 42: 505-510, 2005

180. Budhu A, Forgues M, Ye QH, He P, Zanetti KA, Kammula US, Chen Y, Qin LX, Tang ZY and Wang XW: Prediction of venous metastases, recurrence and prognosis in hepatocellular carcinoma based on a unique immune response signature of the liver microenvironment. Cancer Cell 10: 99-111, 2006

181. Trinchieri G: Interleukin-12 and the regulation of innate resistance and adaptive immunity. Nat Rev Immunol 3: 133-146, 2003

182. Yamashita YI, Shimada M, Hasegawa H, et al: Electroporationmediated interleukin-12 gene therapy for hepatocellular carcinoma in the mice model. Cancer Res 61: 1005-1012, 2001.

183. Leonard JP, Sherman ML, Fisher GL, Buchanan LJ, Larsen G, Atkins MB, Sosman JA, Dutcher JP, Vogelzang NJ and Ryan JL: Effects of single-dose interleukin-12 exposure on interleukin-12associated toxicity and interferon-gamma production. Blood 90 2541-2548, 1997.

184. Sangro B, Mazzolini G, Ruiz J, et al: Phase I trial of intratumoral injection of an adenovirus encoding interleukin-12 for advanced digestive tumors. J Clin Oncol 22: 1389-1397, 2004.

185. Wang L, Yi T, Kortylewski M, Pardoll DM, Zeng D and Yu H: IL-17 can promote tumor growth through an IL-6-Stat3 signaling pathway. J Exp Med 206: 1457-1464, 2009

186. Gu FM, Li QL, Gao Q, Jiang JH, Zhu K, Huang XY, Pan JF, Yan J, Hu JH, Wang Z, Dai Z, Fan J and Zhou J: IL-17 induces AKT-dependent IL-6/JAK2/STAT3 activation and tumor progression in hepatocellular carcinoma. Mol Cancer 10: 150, 2011.

187. Massague J: TGFbeta in cancer. Cell 134: 215-230, 2008.

188. Yamazaki K, Masugi Y and Sakamoto M: Molecular pathogenesis of hepatocellular carcinoma: altering transforming growth factor- $\beta$ signaling in hepatocarcinogenesis. Dig Dis 29 : 284-288, 2011.

189. Bedossa P, Peltier E, Terris B, Franco D and Poynard T: Transforming growth factor-beta 1 (TGF-beta 1) and TGF-beta 1 receptors in normal, cirrhotic, and neoplastic human livers. Hepatology 21: 760-766, 1995.

190. Gomis RR, Alarcon C, Nadal C, van Poznak C and Massague J: C/EBPbeta at the core of the TGFbeta cytostatic response and its evasion in metastatic breast cancer cells. Cancer Cell 10: 203-214, 2006.

191. Murata T, Ohshima T, Yamaji M, Hosaka M, Miyanari Y, Hijikata M and Shimotohno K: Suppression of hepatitis C virus replicon by TGF- $\beta$. Virology 331: 407-417, 2005.

192. Matsuzaki K, Murata M, Yoshida K, et al: Chronic inflammation associated with hepatitis $\mathrm{C}$ virus infection perturbs hepatic transforming growth factor beta signaling, promoting cirrhosis and hepatocellular carcinoma. Hepatology 46: 48-57, 2007.

193. Murata M, Matsuzaki K, Yoshida K, et al: Hepatitis B virus X protein shifts human hepatic transforming growth factor (TGF)beta signaling from tumor suppression to oncogenesis in early chronic hepatitis B. Hepatology 49: 1203-1217, 2009.

194. Sohn BH, Park IY, Lee JJ, et al: Functional switching of TGF-beta1 signalling in liver cancer via epigenetic modulation of a single $\mathrm{CpG}$ site in TTP promoter. Gastroenterology 138 1898-1908, 2010

195. Fransvea E, Angelotti U, Antonaci S and Giannelli G: Blocking transforming growth factor-beta up-regulates E-cadherin and reduces migration and invasion of hepatocellular carcinoma cells. Hepatology 47: 1557-1566, 2008.

196. Giannelli G, Fransvea E, Marinosci F, Bergamini C, Colucci S, Schiraldi $\mathrm{O}$ and Antonaci S: Transforming growth factor-betal triggers hepatocellular carcinoma invasiveness via alpha3beta1 integrin. Am J Pathol 161: 183-193, 2002.
197. Katabami K, Mizuno H, Sano R, Saito Y, Ogura M, Itoh S and Tsuji T: Transforming growth factor-beta1 upregulates transcription of alpha3 integrin gene in hepatocellular carcinoma cells via Ets-transcription factor-binding motif in the promoter region. Clin Exp Metastasis 22: 539-548, 2005.

198. Mazzocca A,Fransvea E,Lavezzari G, Antonaci S and Giannelli G: Inhibition of transforming growth factor beta receptor I kinase blocks hepatocellular carcinoma growth through neo-angiogenesis regulation. Hepatology 50: 1140-1151, 2009.

199. Mazzocca A, Fransvea E, Dituri F, Lupo L, Antonaci S and Giannelli G: Downregulation of connective tissue growth factor by inhibition of transforming growth factor beta blocks the tumor-stroma cross talk and tumor progression in hepatocellular carcinoma. Hepatology 51: 523-534, 2010.

200. Peinado H, Quintanilla M and Cano A: Transforming growth factor beta-1 induces snail transcription factor in epithelial cell lines: mechanisms for epithelial mesenchymal transitions. J Biol Chem 278: 21113-21123, 2003.

201. Van Zijl F, Mair M, Csiszar A, Schneller D, Zulehner G, Huber H, Eferl R, Beug H, Dolznig H and Mikulits W: Hepatic tumorstroma crosstalk guides epithelial to mesenchymal transition at the tumor edge. Oncogene 28: 4022-4033, 2009.

202. Wang B, Hsu SH, Majumder S, Kutay H, Huang W, Jacob ST and Ghoshal K: TGFbeta mediated upregulation of hepatic miR-181b promotes hepatocarcinogenesis by targeting TIMP3. Oncogene 29: 1787-1797, 2010.

203. Huang S, He X, Ding J, Liang L, Zhao Y, Zhang Z, Yao X, Pan Z, Zhang P, Li J, Wan D and Gu J: Upregulation of miR-23a approximately 27 a approximately 24 decreases transforming growth factor-beta-induced tumor-suppressive activities in human hepatocellular carcinoma cells. Int J Cancer 123: 972-978, 2008.

204. Okumoto K, Hattori E, Tamura K, Kiso S, Watanabe H, Saito K, Saito T, Togashi $\mathrm{H}$ and Kawata S: Possible contribution of circulating transforming growth factor- $\beta 1$ to immunity and prognosis in unresectable hepatocellular carcinoma. Liver Int 24 : 21-28, 2004

205. Kim YJ, Lee HS, Im JP, Min BH, Kim HD, Jeong JB, Yoon JH, Kim CY, Kim MS, Kim JY, Jung JH, Kim LH, Park BL and Shin HD: Association of transforming growth factor- $\beta 1$ gene polymorphisms with a hepatocellular carcinoma risk in patients with chronic hepatitis B virus infection. Exp Mol Med 35: 196-202, 2003.

206. Kim YJ, Kim HY, Kim JS, Lee JH, Yoon JH, Kim CY, Park BL, Cheong HS, Bae JS, Kim S, Shin HD and Lee HS: Putative association of transforming growth factor-alpha polymorphisms with clearance of hepatitis B virus and occurrence of hepatocellular carcinoma in patients with chronic hepatitis B virus infection. J Viral Hepat 17: 518-526, 2010.

207. Xiang TX, Cheng N, Li XN and Wu XP: Association between transforming growth factor- $\beta 1$ polymorphisms and hepatocellular cancer risk: a meta-analysis. Hepatol Res doi: 10.1111/j.1872034X.2011.00958.x [Epub ahead of print] 2012.

208. Gurtner GC, Werner S, Barrandon Y and Longaker MT: Wound repair and regeneration. Nature 453: 314-321, 2008

209. Presta M, Dell'Era P, Mitola S, Moroni E, Ronca R and Rusnati M: Fibroblast growth factor/fibroblast growth factor receptor system in angiogenesis. Cytokine Growth Factor Rev 16: $159-178,2005$

210. Ho HK, Pok S, Streit S, Ruhe JE, Hart S, Lim KS, Loo HL, Aung MO, Lim SG and Ullrich A: Fibroblast growth factor receptor 4 regulates proliferation, anti-apoptosis and alpha-fetoprotein secretion during hepatocellular carcinoma progression and represents a potential target for therapeutic intervention. J Hepatol 50: 118-127, 2009.

211. Amann T, Bataille F, Spruss T, et al: Reduced expression of fibroblast growth factor receptor 2IIIb in hepatocellular carcinoma induces a more aggressive growth. Am J Pathol 176: 1433-1442, 2010.

212. Boix L, Rosa JL, Ventura F, Castells A, Bruix J, Rodés J and Bartrons R: c-MET mRNA overexpression in human hepatocellular carcinoma. Hepatology 19: 88-91, 1994.

213. Kiss A, Wang NJ, Xie JP and Thorgeirsson SS: Analysis of transforming growth factor (TGF)-alpha/epidermal growth factor receptor, hepatocyte growth factor/c-met, TGF-beta receptor type II, and p53 expression in human hepatocellular carcinomas. Clin Cancer Res 3: 1059-1066, 1997

214. Tavian D, De PG, Benetti A, Portolani N, Giulini SM and Barlati S: $\mathrm{u}-\mathrm{PA}$ and c-MET mRNA expression is co-ordinately enhanced while hepatocyte growth factor mRNA is down-regulated in human hepatocellular carcinoma. Int J Cancer 87: 644-649, 2000. 
215. Ueki T, Fujimoto J, Suzuki T, Yamamoto H and Okamoto E: Expression of hepatocyte growth factor and its receptor, the c-met proto-oncogene, in hepatocellular carcinoma. Hepatology 25: 619-623, 1997.

216. Kaposi-Novak P, Lee JS, Gomez-Quiroz L, Coulouarn C, Factor VM and Thorgeirsson SS: Met-regulated expression signature defines a subset of human hepatocellular carcinomas with poor prognosis and aggressive phenotype. J Clin Invest 116: 1582-1595, 2006.

217. Hirschi KK and D'Amore PA: Control of angiogenesis by the pericyte: molecular mechanisms and significance. EXS 79: 419-428, 1997.

218. Semela D and Dufour JF: Angiogenesis and hepatocellular carcinoma. J Hepatol 41: 864-880, 2004.

219. Avila MA, Berasain C, Sangro B and Prieto J: New therapies for hepatocellular carcinoma. Oncogene 25: 3866-3884, 2006.

220. Bangoura G, Liu ZS, Qian Q, Jiang CQ, Yang GF and Jing S: Prognostic significance of HIF-2alpha/EPAS1 expression in hepatocellular carcinoma. World J Gastroenterol 13: 3176-3182, 2007

221. Liu LP, Liang HF, Chen XP, Zhang WG, Yang SL, Xu T and Ren L: The role of NFkappaB in Hepatitis $b$ virus $X$ proteinmediated upregulation of VEGF and MMPs. Cancer Invest 28 : 443-451, 2010.

222. Yang JC, Teng CF, Wu HC, Tsai HW, Chuang HC, Tsai TF, Hsu YH, Huang W, Wu LW and Su IJ: Enhanced expression of vascular endothelial growth factor-A in ground glass hepatocytes and its implication in hepatitis B virus hepatocarcinogenesis. Hepatology 49: 1962-1971, 2009.

223. Dhar DK, Naora H, Yamanoi A, Ono T, Kohno H and Otani H: Requisite role of VEGF receptors in angiogenesis of hepatocellular carcinoma: a comparison with angiopoietin/Tie pathway. Anticancer Res 22: 379-386, 2002.

224. Ng IO, Poon RT, Lee JM, Fan ST, Ng M and Tso WK: Microvesse density, vascular endothelial growth factor and its receptors Flt-1 and Flk-1/KDR in hepatocellular carcinoma. Am J Clin Patho 116: 838-845, 2001

225. Poon RT, Ho JW, Tong CS, Lau C, Ng IO and Fan ST: Prognostic significance of serum vascular endothelial growth factor and endostatin in patients with hepatocellular carcinoma. Br J Surg 91: 1354-1360, 2004.

226. Shimamura T, Saito S, Morita K, Kitamura T, Morimoto M, Kiba T,Numata K, Tanaka K and Sekihara H: Detection of vascular endothelial growth factor and its receptor expression in human hepatocellular carcinoma biopsy specimens. J Gastroenterol Hepatol 15: 640-646, 2000

227. Lian Z, Liu J, Wu M, Wang HY, Arbuthnot P, Kew M and Feitelson MA: Hepatitis B $\mathrm{x}$ antigen up-regulates vascular endothelial growth factor receptor 3 in hepatocarcinogenesis. Hepatology 45: 1390-1399, 2007.

228. Yamaguchi R, Yano H, Iemura A, Ogasawara S, Haramaki M and Kojiro M: Expression of vascular endothelial growth factor in human hepatocellular carcinoma. Hepatology 28: 68-77, 1998.

229. Poon RT, Lau C, Yu WC, Fan ST and Wong J: High serum levels of vascular endothelial growth factor predict poor response to transarterial chemoembolization in hepatocellular carcinoma: a prospective study. Oncol Rep 11: 1077-1084, 2004.

230. Chao Y, Li CP, Chau GY, Chen CP, King KL, Lui WY, Yen SH, Chang FY, Chan WK and Lee SD: Prognostic significance of vascular endothelial growth factor, basic fibroblast growth factor, and angiogenin in patients with resectable hepatocellular carcinoma after surgery. Ann Surg Oncol 10: 355-362, 2003.

231. Li XM, Tang ZY, Zhou G, Lui YK and Ye SL: Significance of vascular endothelial growth factor mRNA expression in invasion and metastasis of hepatocellular carcinoma. J Exp Clin Cancer Res 17: 13-17, 1998.

232.Zhou J, Tang ZY, Fan J, Wu ZQ, Li XM, Liu YK, Liu F, Sun HC and Ye SL: Expression of platelet-derived endothelial cell growth factor and vascular endothelial growth factor in hepatocellular carcinoma and portal vein tumor thrombus. J Cancer Res Clin Oncol 126: 57-61, 2000.

233. Parks WC, Wilson CL and Lopez-Boado YS: Matrix metalloproteinases as modulators of inflammation and innate immunity. Nat Rev Immunol 4: 617-629, 2004.

234. Libra M, Scalisi A, Vella N, Clementi S, Sorio R, Stivala F, Spandidos DA and Mazzarino C: Uterine cervical carcinoma: role of matrix metalloproteinases (Review). Int J Oncol 34: 897-903, 2009.

235. Kessenbrock K, Plaks V and Werb Z: Matrix metalloproteinases: regulators of the tumor microenvironment. Cell 141: 52-67, 2010.
236. Bourboulia D and Stetler-Stevenson WG: Matrix metalloproteinases (MMPs) and tissue inhibitors of metalloproteinases (TIMPs): positive and negative regulators in tumor cell adhesion. Semin Cancer Biol 20: 161-168, 2010.

237. Ou DP, Tao YM, Tang FQ and Yang LY: The hepatitis B virus $\mathrm{X}$ protein promotes hepatocellular carcinoma metastasis by upregulation of matrix metalloproteinases. Int J Cancer 120: 1208-1214, 2007.

238. Yu FL, Liu HJ, Lee JW, Liao MH and Shih WL: Hepatitis B virus $\mathrm{X}$ protein promotes cell migration by inducing matrix metalloproteinase-3. J Hepatol 42: 520-527, 2005

239. Lara-Pezzi E, Gómez-Gaviro MV, Gálvez BG, Mira E, Iñiguez MA, Fresno M, Martínez-A C, Arroyo AG and LópezCabrera M: The hepatitis B virus X protein promotes tumor cell invasion by inducing membrane-type matrix metalloproteinase-1 and cyclooxygenase-2 expression. J Clin Invest 110: 1831-1838, 2002 .

240. Zhao XL, Sun T, Che N, Sun D, Zhao N, Dong XY, Gu Q, Yao Z and Sun BC: Promotion of hepatocellular carcinoma metastasis through matrix metalloproteinase activation by epithelial-mesenchymal transition regulator twist1. J Cell Mol Med 15: 691-700, 2011.

241. Yu Q and Stamenkovic I: Localization of matrix metalloproteinase 9 to the cell surface provides a mechanism for CD44-mediated tumor invasion. Genes Dev 13: 35-48, 1999.

242. Mitsiades N, Yu WH, Poulaki V, Tsokos M and Stamenkovic I: Matrix metalloproteinase-7-mediated cleavage of Fas ligand protects tumor cells from chemotherapeutic drug cytotoxicity. Cancer Res 61: 577-581, 2001

243. Lin WW and Karin M: A cytokine-mediated link between innate immunity, inflammation, and cancer. J Clin Invest 117: $1175-1183,2007$.

244. Manicone AM and McGuire JK: Matrix metalloproteinases as modulators of inflammation. Semin Cell Dev Biol 19: 34-41, 2008.

245. Kohga K, Tatsumi T, Takehara T, Tsunematsu H, Shimizu S, Yamamoto M, Sasakawa A, Miyagi T and Hayashi N: Expression of CD133 confers malignant potential by regulating metalloproteinases in human hepatocellular carcinoma. J Hepatol 52: $872-879,2010$

246. Littlepage LE, Sternlicht MD, Rougier N, et al: Matrix metalloproteinases contribute distinct roles in neuroendocrine prostate carcinogenesis, metastasis, and angiogenesis progression. Cancer Res 70: 2224-2234, 2010

247. Cheng JC, Chou CH, Kuo ML and Hsieh CY: Radiationenhanced hepatocellular carcinoma cell invasion with MMP-9 expression through PI3K/Akt/NF-kappaB signal transduction pathway. Oncogene 25: 7009-7018, 2006.

248. Chen JS, Wang Q, Fu XH, Huang XH, Chen XL, Cao LQ, Chen LZ, Tan HX, Li W, Bi J and Zhang LJ: Involvement of $\mathrm{PI} 3 \mathrm{~K} / \mathrm{PTEN} / \mathrm{AKT} / \mathrm{mTOR}$ pathway in invasion and metastasis in hepatocellular carcinoma: association with MMP-9. Hepatol Res 39: 177-186, 2009.

249. Takafuji V, Forgues M, Unsworth E, Goldsmith P and Wang XW: An osteopontin fragment is essential for tumor cell invasion in hepatocellular carcinoma. Oncogene 26: 6361-6371, 2007.

250. Arii S, Mise M, Harada T, Furutani M, Ishigami S, Niwano M, Mizumoto M, Fukumoto $\mathrm{M}$ and Imamura M: Overexpression of matrix metalloproteinase 9 gene in hepatocellular carcinoma with invasive potential. Hepatology 24: 316-322, 1996.

251. Fernández CA, Yan L, Louis G, Yang J, Kutok JL and Moses MA: The matrix metalloproteinase-9/neutrophil gelatinase-associated lipocalin complex plays a role in breast tumor growth and is present in the urine of breast cancer patients. Clin Cancer Res 11: 5390-5395, 2005.

252. Kubben FJ, Sier CF, Hawinkels LJ, et al: Clinical evidence for a protective role of lipocalin-2 against MMP-9 autodegradation and the impact for gastric cancer. Eur J Cancer 43: 1869-1876, 2007.

253. Smith ER, Zurakowski D, Saad A, Scott RM and Moses MA: Urinary biomarkers predict brain tumor presence and response to therapy. Clin Cancer Res 14: 2378-2386, 2008.

254.Zhang H, Xu L, Xiao D, et al: Upregulation of neutrophil gelatinase-associated lipocalin in oesophageal squamous cell carcinoma: significant correlation with cell differentiation and tumour invasion. J Clin Pathol 60: 555-561, 2007.

255. Kim JR and Kim CH: Association of a high activity of matrix metalloproteinase-9 to low levels of tissue inhibitors of metalloproteinase-1 and -3 in human hepatitis B-viral hepatoma cells. Int J Biochem Cell Biol 36: 2293-2306, 2004. 
256. Xia D, Yan LN, Xie JG, Tong Y, Yan ML, Wang XP, Zhang MM and Zhao LY: Overexpression of TIMP-1 mediated by recombinant adenovirus in hepatocellular carcinoma cells inhibits proliferation and invasion in vitro. Hepatobiliary Pancreat Dis Int 5: 409-415, 2006.

257. Qi JH, Ebrahem Q, Moore N, Murphy G, Claesson-Welsh L, Bond M, Baker A and Anand-Apte B: A novel function for tissue inhibitor of metalloproteinases-3 (TIMP3): inhibition of angiogenesis by blockage of VEGF binding to VEGF receptor-2. Nat Med 9: 407-415, 2003

258. Zhang H, Wang YS, Han G and Shi Y: TIMP-3 gene transfection suppresses invasive and metastatic capacity of human hepatocarcinoma cell line HCC-7721. Hepatobiliary Pancreat Dis Int 6: 487-491, 2007.

259. Chen X, Cheung ST, So S, Fan ST, Barry C, Higgins J, Lai KM, Ji J, Dudoit S, Ng IO, van de Rijn M, Botstein D and Brown PO: Gene expression patterns in human liver cancers. Mol Biol Cell 13: 1929-1939, 2002.

260.Lee JS, Heo J, Libbrecht L, et al: A novel prognostic subtype of human hepatocellular carcinoma derived from hepatic progenitor cells. Nat Med 12: 410-416, 2006.

261. Wu XZ, Xie GR and Chen D: Hypoxia and hepatocellular carcinoma: the therapeutic target for hepatocellular carcinoma. J Gastroenterol Hepatol 22: 1178-1182, 2007.

262. Liu L, Zhu XD, Wang WQ, Shen Y, Qin Y, Ren ZG, Sun HC and Tang ZY: Activation of beta-catenin by hypoxia in hepatocellular carcinoma contributes to enhanced metastatic potential and poor prognosis. Clin Cancer Res 16: 2740-2750, 2010.

263. Hamaguchi T, Iizuka N, Tsunedomi R, Hamamoto Y, Miyamoto T Iida M, Tokuhisa Y, Sakamoto K, Takashima M, Tamesa T and Oka M: Glycolysis module activated by hypoxia-inducible factor lalpha is related to the aggressive phenotype of hepatocellular carcinoma. Int J Oncol 33: 725-731, 2008.

264. Roberts LR and Gores GJ: Hepatocellular carcinoma: molecular pathways and new therapeutic targets. Semin Liver Dis 25 212-225, 2005.

265. Gollob JA, Wilhelm S, Carter C and Kelley SL: Role of Raf kinase in cancer: therapeutic potential of targeting the Raf/MEK/ERK signal transduction pathway. Semin Oncol 33: 392-406, 2006.

266.Leicht DT, Balan V, Kaplun A, Singh-Gupta V, Kaplun L, Dobson $\mathrm{M}$ and Tzivion G: Raf kinases: function, regulation and role in human cancer. Biochim Biophys Acta 1773: 1196-1212, 2007.

267. Yoshida T, Hisamoto T, Akiba J, et al: Spreds, inhibitors of the Ras/ERK signal transduction, are dysregulated in human hepatocellular carcinoma and linked to the malignant phenotype of tumors. Oncogene 25: 6056-6066, 2006.

268. Schuierer MM, Bataille F, Weiss TS, Hellerbrand C and Bosserhoff AK: Raf kinase inhibitor protein is downregulated in hepatocellular carcinoma. Oncol Rep 16: 451-456, 2006.

269. Schmitz KJ, Wohlschlaeger J, Lang H, Sotiropoulos GC, Malago M, Steveling K, Reis H, Cicinnati VR, Schmid KW and Baba HA: Activation of the ERK and AKT signalling pathway predicts poor prognosis in hepatocellular carcinoma and ERK activation in cancer tissue is associated with hepatitis $\mathrm{C}$ virus infection. J Hepatol 48: 83-90, 2008.

270. McKillop IH, Schmidt CM, Cahill PA and Sitzmann JV: Altered expression of mitogen-activated protein kinases in a rat model of experimental hepatocellular carcinoma. Hepatology 26: $1484-1491,1997$.
271. Ito Y, Sasaki Y, Horimoto M, et al: Activation of mitogenactivated protein kinases/extracellular signal-regulated kinases in human hepatocellular carcinoma. Hepatology 27: 951-958, 1998.

272. Huynh H, Chow PK and Soo KC: AZD6244 and doxorubicin induce growth suppression and apoptosis in mouse models of hepatocellular carcinoma. Mol Cancer Ther 6: 2468-2476, 2007.

273. Hwang YH, Choi JY, Kim S, Chung ES, Kim T, Koh SS, Lee B, Bae SH, Kim J and Park YM: Over-expression of c-raf-1 protooncogene in liver cirrhosis and hepatocellular carcinoma. Hepatol Res 29: 113-121, 2004.

274. Feng DY, Zheng H, Tan Y and Cheng RX: Effect of phosphorylation of MAPK and Stat 3 and expression of c-fos and c-jun proteins on hepatocarcinogenesis and their clinical significance. World J Gastroenterol 7: 33-36, 2001.

275. Alexia C, Fallot G, Lasfer M, Schweizer-Groyer G and Groyer A: An evaluation of the role of insulin-like growth factors (IGF) and of type-I IGF receptor signalling in hepatocarcinogenesis and in the resistance of hepatocarcinoma cells against drug-induced apoptosis. Biochem Pharmacol 68: 1003-1015, 2004.

276. Desbois-Mouthon C, Cadoret A, Blivet-van Eggelpoël MJ, Bertrand F, Cherqui G, Perret C and Capeau J: Insulin and IGF-1 stimulate the beta-catenin pathway through two signalling cascades involving GSK-3beta inhibition and Ras activation. Oncogene 20: 252-259, 2001.

277. Hu TH, Huang CC, Lin PR, Chang HW, Ger LP, Lin YW, Changchien CS, Lee CM and Tai MH: Expression and prognostic role of tumor suppressor gene PTEN/MMAC1/TEP1 in hepatocellular carcinoma. Cancer 97: 1929-1940, 2003.

278. Villanueva A, Chiang DY, Newell P, et al: Pivotal role of mTOR signaling in hepatocellular carcinoma. Gastroenterology 135: 1972-1983, 2008.

279. De La CA, Romagnolo B, Billuart P, et al: Somatic mutations of the beta-catenin gene are frequent in mouse and human hepatocellular carcinomas. Proc Natl Acad Sci USA 95: 8847-8851, 1998.

280. Giles RH, van Es JH and Clevers H: Caught up in a Wnt storm: Wnt signaling in cancer. Biochim Biophys Acta 1653: 1-24, 2003.

281. Hoshida Y, Nijman SM, Kobayashi M, et al: Integrative transcriptome analysis reveals common molecular subclasses of human hepatocellular carcinoma. Cancer Res 69: 7385-7392, 2009.

282. Cheng AL, Kang YK, Chen Z, et al: Efficacy and safety of sorafenib in patients in the Asia-Pacific region with advanced hepatocellular carcinoma: a phase III randomised, double-blind, placebo-controlled trial. Lancet Oncol 10: 25-34, 2009.

283. Kaspar M, Zardi L and Neri D: Fibronectin as target for tumor therapy. Int J Cancer 118: 1331-1339, 2006.

284. Liu F, Wang P, Jiang X, Tan G, Qiao H, Jiang H, Krissansen GW and Sun X: Antisense hypoxia-inducible factor 1alpha gene therapy enhances the therapeutic efficacy of doxorubicin to combat hepatocellular carcinoma. Cancer Sci 99: 2055-2061, 2008 .

285. WeiXing C, Tiantian H, Qun N, Chaohui Y and Ping X: Inhibitory effect of hypoxia inducible factor-1 antisense oligonucleotide on growth of human hepatocellular carcinoma cells. Med Oncol 25: $88-92,2008$ 